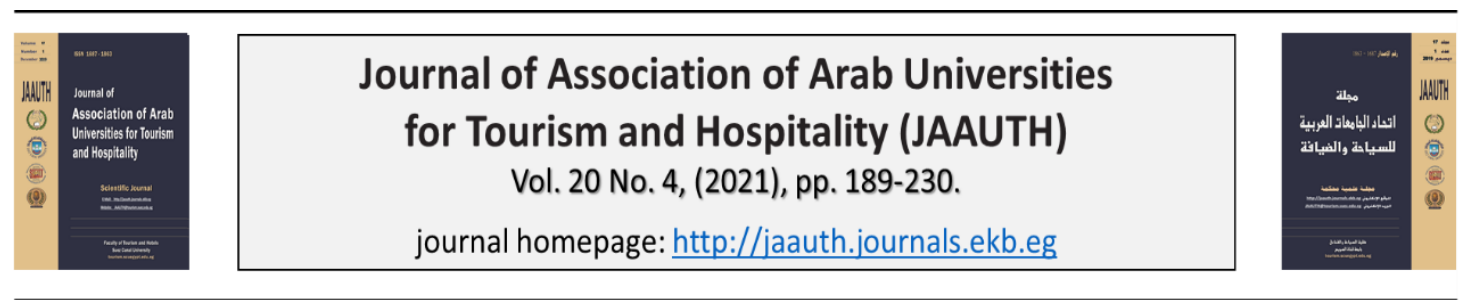

\title{
Ritual of Cutting Grain in Theban Temples: An Overview of the Concept of the Divine and Royal Fertility
}

\section{Youmna Adel Zaki Nasr \\ Tourist Guiding Department, Faculty of Tourism and Hotels, Alexandria University}

\section{ARTICLE INFO ABSTRACT}

Keywords:

Ritual; Grain;

Harvester; Fertility;

Enemies.

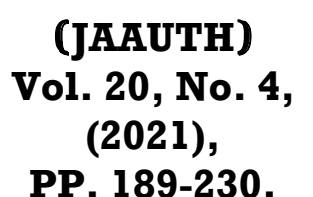

Cutting grain is a remarkable Ramesside ritual in the Theban temples during the New Kingdom. Five scenes are found depicting the king as a harvester cutting grain before the deities of fertility in the New Kingdom temples of Thebes. The ritual was rarely represented in the New Kingdom and it was performed in the Theban temples only during the reigns of Kings Ramesses II and Ramesses III. After the reign of King Ramesses III, this ritual was no more attested in the Theban temples. However, it regained its importance once more during the Ptolemaic Period. Grain crops were sacred and aphrodisiac offerings of the male sexual potency and masculine virility during the festival of the fertility-god Min. Therefore, the image of the self-created god Amun-Re in his form as Kamutef, the fertility-god Min, and the fecund-god Hapy of the fertile Nile and flooding dominated the scenes of the ritual, in reference to the role of the male deities in fecundation, regeneration, birth, and rebirth.

\section{Introduction}

There were several ancient Egyptian rituals in the honor of the god, in which the king would come to participate in a religious ceremony consisting of a series of actions performed before the deity. One of the most important and rare rituals that was performed during the New Kingdom in the Theban temples is the ritual of cutting grain before the gods to ensure the fertility ${ }^{(1)}$. This ritual occurred in the Great Temple of Amun-Re at Karnak, the Ramesseum, and the Temple of King Ramesses III at Medinet Habu. It commemorates the annual event of cutting corn that began to be happened in the first month of the harvest season since the time of the Old Kingdom and up to the Ptolemaic Period ${ }^{(2)}$. The direct aim of such event was to obtain the divine favor and to ensure the promising of a new year of abundant harvests. On the other hand, this event alluded indirectly to the continuation of the power and the fertility of the $\operatorname{king}^{(3)}$.

\section{Cutting Grain in the Ancient Egyptian Language:}

The annual ritual of cultivated cereals with the sickle was named in the ancient

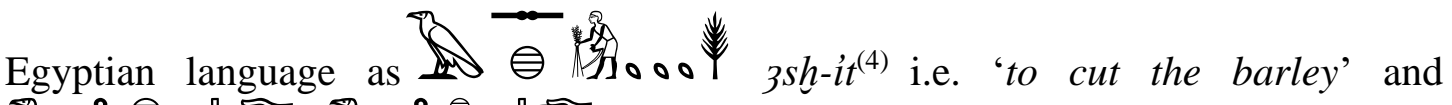

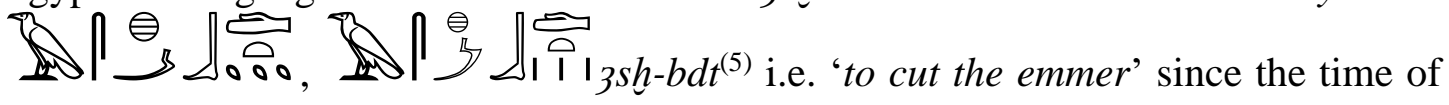


the Old Kingdom. The terminology

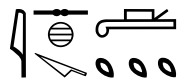

$i s h$-it $)^{(7)}$ continued to be used up to the Ptolemaic Period in Edfu Temple.

These two comparable terms consist of two parts: $\theta$,

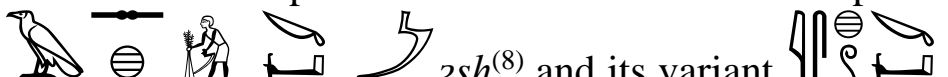

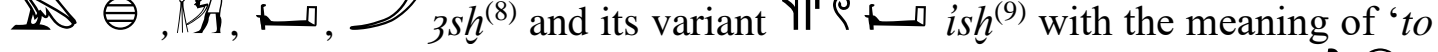

reap', 'to mow', 'to cut grain', or 'to harvest' definitely with the sickle and 1000 ,

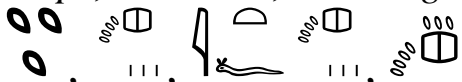

○, $11,1 \times 11,8^{\circ}, 000$ it, which means 'grain' and 'barley ${ }^{\text {(10) }}$. In the same way, the term $3 s h-b d t$ is also composed of two words, the first of which includes the

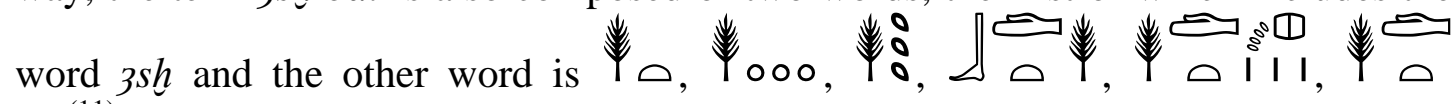
$b d t^{(11)}$ i.e. 'emmer'.

The word $b d t$ occupied since the time of the Pyramid Texts. During the Middle Kingdom and Late Period, the latter word was often written as

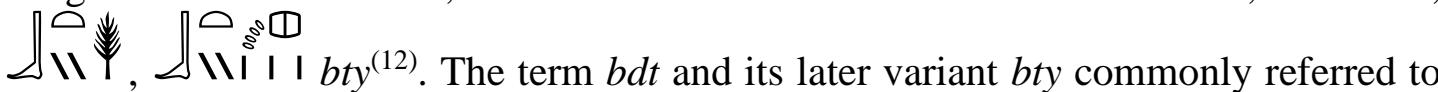
an arable plant and a popular type of wheat and considered as its crop in ancient $\operatorname{Egypt}^{(13)}$.

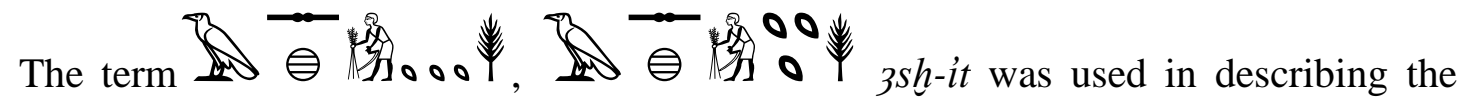
event of the cutting of the barley before the tomb-owner in the cemeteries of Giza, Saqqara $^{(14)}$, Meir ${ }^{(15)}$, and Sheik Said ${ }^{(16)}$ during the time of the Old Kingdom. It was inscribed for the first time in the Fifth Dynasty Mastaba of Nefer I (G 4761) in the western cemetery of $\mathrm{Giza}^{(17)}$. In the Pyramid Texts, the term it was used in Utterance 667A (Spell \$1936d) in reference to the event of the mowing of the barley for the so called $f(\Delta)_{w 3 g}$-festival ${ }^{(18)}$. The term $3 s h$-it was also used during the First Intermediate Period as was recorded on the fragment of Ipiankhu that is preserved in the Oriental Institute Museum at Chicago $(17366)^{(19)}$.

In Spell 330 in the Coffin Texts, the deceased was assimilated to the bty-emmer, so that he would never perish in the afterworld ${ }^{(20)}$. In Spells $67^{(21)}, 72^{(22)}$, $571^{(23)}$, and $725^{(24)}$ in the Coffin Texts, the emmer was reaped for the deceased in its

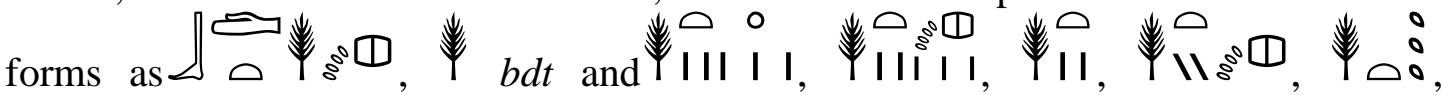

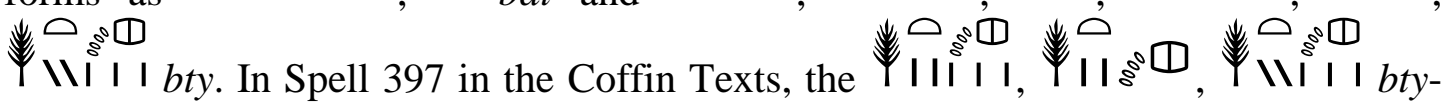
emmer was mentioned to be reaped before god Min of Coptos in his festival ${ }^{(25)}$. In Spell 398 in the Coffin Texts, the mission of reaping the 
幽密四

I I I bty-emmer was assigned to the gods in the afterlife ${ }^{(26)}$. Several spells of the Coffin Texts revealed the high nutritional quality of the emmer grain as a type of food for the deceased king. In Spells $203^{(27)}, 225^{(28)}, 473^{(29)}$ in the Coffin Texts, it was said that the deceased lives on the 幽四

YII0:0bty-emmer as the main eternal nourishment in order to be able to become a justified spirit in the otherworld and to be vindicated against his foes. In Spells $159^{(30)}$

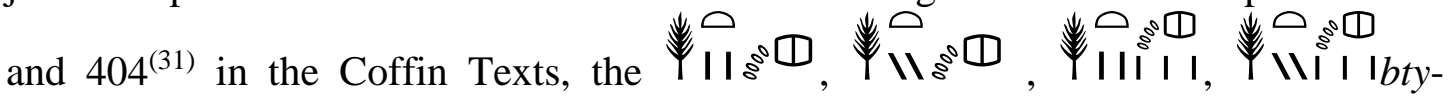
emmer of seven cubits was described to be cultivated in the Iaru Field in the hereafter

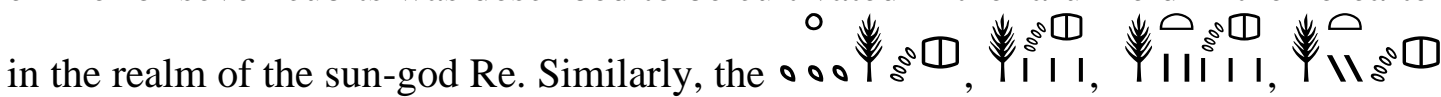
幽四

, Y II I Ibty-emmer was cultivated in the Field of Offerings in the hereafter as was recorded in Spells $466^{(32)}$ and $467^{(33)}$ in the Coffin Texts. In Spell 228 in the Coffin

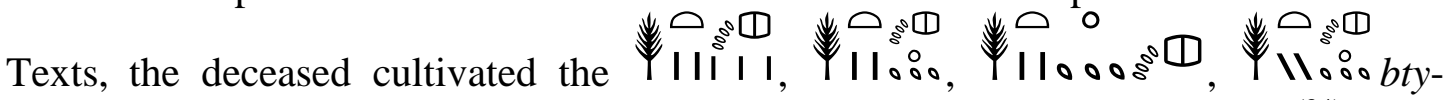
emmer to be presented as offerings to the gods in order to make them content ${ }^{(34)}$.

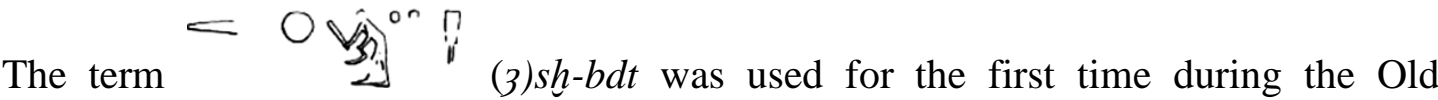
Kingdom in reference to the event of the cutting of the emmer by using the sickle ${ }^{(35)}$. Meanwhile, the term was firstly utilized in a very limited scale in the individual sphere at Giza and then it began to be widely used in the royal sector at Saqqara. Individually, the term was inscribed as an indication of the reaping of the emmer before the tomb-owner in a single private mastaba from the Fifth Dynasty, called the Mastaba of Jj-mry ( $\mathrm{G}$ 6020) in the western cemetery of $\mathrm{Giza}^{(36)}$. In the royal sector, the term was recorded in the Sixth Dynasty Pyramids of Kings Teti, Pepi I, Merenre I, and Pepi II and the Pyramid of Queen Neith at Saqqara during the time of the Old

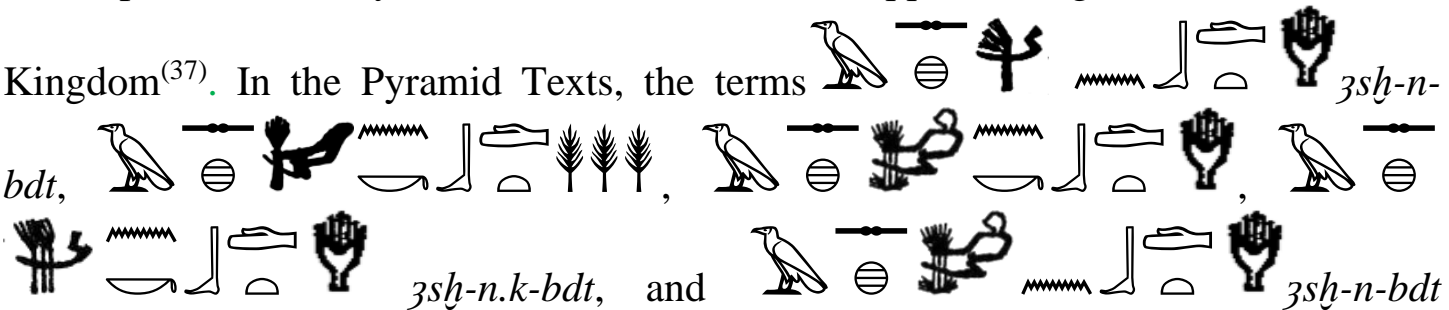
were inscribed in Utterances $373^{(38)}, 619^{(39)}$, and 691B ${ }^{(40)}$ (Spells $§ 657 \mathrm{a}, \S 1748 \mathrm{~b}$, and $\S 2128 \mathrm{c}$ ) respectively in reference to the event of the mowing of the emmer to be used in the celestial world in making the offerings of the monthly and half-monthly

festivals. Moreover, the terms $3 s h . k-b d t$ and $\theta$

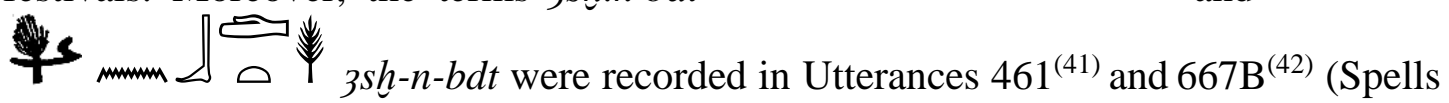
$\S 874 \mathrm{a}$ and $\S 1950 \mathrm{a})$ respectively in the Pyramid Texts as an indication of the reaping of the wheat to be used in making the yearly sustenance of the king to secure his necessities of life in the Fields of the Iaru. 
After a time of neglection after the Pyramid Texts, the ritual of

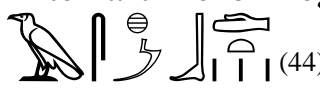
3sh-bdt i.e. 'Cutting grain'(45) regained its importance during the New Kingdom as an episode in the Festival of god Min as was depicted in the Temple of Ramesseum (Fig. 4) and the Temple of Medinet Habu (Fig. 5) ${ }^{(46)}$.

The ancient Egyptians used the chipped-stone sickle as the primary tool for harvesting ears of wheat in their own fields ${ }^{(47)}$. This might interpret the reason of writing several determinatives of a sickle 3 , a sickle cutting sheaves of grain ifs, a knife $\nsim$, a bent man cutting sheaves of grain by using a sickle s

, and a mutilated glyph of arms cutting an ear of grain by a sickle definition of the ritual since the time of the Old Kingdom, thus alluding to the harvest-time and symbolizing the generative powers of creation, fertility, and resurrection of both the harvester and the god to whom the grain was presented as sacred offerings.

\section{Ritual Scenes of Cutting Grain in the Theban Temples:}

Cutting sheaves of grain formed a noticeable ritual scenes in the Theban temples during the New Kingdom. The Ramesside kings preferred to cut the ears of grain to several fertility deities. Five scenes are found depicting King Ramesses II and King Ramesses III cutting grain before gods Amun-Re-Kamutef, Min, and Hapy in the Theban temples during the New Kingdom (Figs. 2-6). Being a pure religious ritual that has a primary objective ensuring the divine and royal fertility and a symbolic aim of destructing the foes, the versions of the rituals were distributed in Thebes in three temples. The ritual is a motif of decoration in the hypostyle hall (Fig. 2) and on the exterior girdle wall in the Great Temple of Amun-Re at Karnak (Fig. 3), on the second pylon in the Ramesseum (Fig. 4), and in the second court (Fig. 5) and side room 26 in the Great Temple of Medinet Habu (Fig. 6). The versions of the ritual are identical to a great extent. However, there are nuances that are often not easy to appreciate with accuracy. The five versions of the ritual could be categorized according to the participated deity in the ritual as follows:

\subsection{Ritual of Cutting Grain in the Presence of God Amun-Re-Kamutef:}

God Amun-Re-Kamutef participated in the ritual of cutting sheaves of grain in two different places in the Great Temple of Amun-Re at Karnak including the interior of the hypostyle hall (Fig. 2) $)^{(48)}$ and the exterior girdle wall (Fig. 3) ${ }^{(49)}$. In these two versions at Karnak, King Ramesses II is represented participating in the ritual of the cutting of a sheaf of grain before god Amun-Re ${ }^{(50)}$, the supreme god of Thebes and the king of the gods ${ }^{(51)}$, in his form as Kamutef as follows:

3.1.1. God Amun-Re-Kamutef stands on a pedestal and covered in a shroud in the same manner as god Min ${ }^{(52)}$. He is shown with a curved beard and wrapped in a tight fitting garment and resembles a mummy. He appears as an anthropomorphic male deity with a curved beard and a masculine body in his form as an ithyphallic-god ${ }^{(53)}$. 
He is represented with an erected phallus and $n h$-flail in his raised right hand. He wears a crown with two feathers . Around his forehead, he wears a ribbon that trails to the ground.

3.1.2. King Ramesses II faces the god and wears a light tunic or blouse and a long pointed skirt as well as the tail of the bull. His head is surmounted with a headdress in the hypostyle hall. On the outer girdle wall of King Thutmoses III, King Ramesses II

is represented wearing the ${ }_{\text {hpršs-Blue Crown protected by the uraeus }}^{(54)}$. The right leg of the king is advenced one step forward. He carries a sickle in his left hand and cuts a sheaf of emmer wheat grasped by his right hand. Between the figures of the god and the king, there are one sacrificial offering table in the hypostyle hall and two on the girdle wall loaded with offerings including the lettuce as a sacred sex symbol of the ithyphallic Kamutef ${ }^{(55)}$.

3.1.3. Behind the god, there is a shrine heaped with plants. In the hypostyle hall, the vulture-goddess Nekhbet is shown hovering above the king to protect his royalty ${ }^{(56)}$.

3.1.4. The accompanying texts run as follows:

3.1.4.1. The text, which accompanies the scene of mowing grain in the version of the ritual in the hypostyle hall at Karnak (Fig. 2), runs as follows:

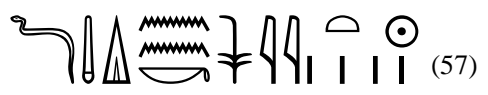

$\underline{d} d-m d w$ di.n n.k nswyt Re

'Words spoken: (I) have given to you the kingship of $R e^{\text {'(58) }}$.

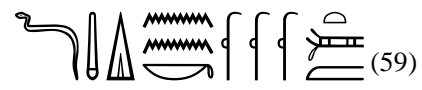

dd-mdw di.n n.k rnpwt 'Itm

'Words spoken: (I) have given to you the years of Atum'(60).

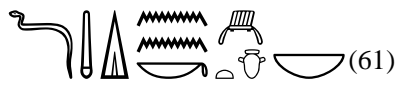

$\underline{d} d-m d w$ di.n n.k $3 w t-i b n b$

'Words spoken: (I) have given to you all joy'(62).

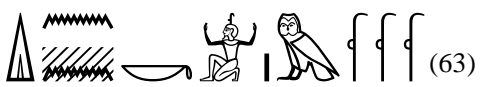

di.n (n). $k$ ḥh $m$ rnpwt

'(I) have given to you a million years' ${ }^{\text {(64) }}$.

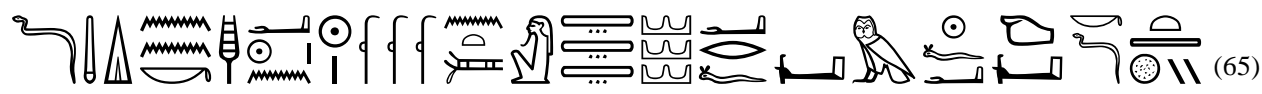


$\underline{d} d-m d w$ di.n n.k 'h' $n R^{\prime}$ 'rnpwt n 'Itm tzw ḩsswt 'rf $m$ hf'. $k \underline{d}$ t sp-2

'Words spoken: (I) have given to you the lifetime of Re and the years of Atum, the flat lands and the hill countries being bundled in your grasp forever and ever ${ }^{(66)}$.

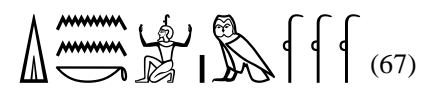

di.n.(i) $n . k h h h(w) m$ rnpwt

'I have given to you millions of years' ${ }^{\prime}(68)$.

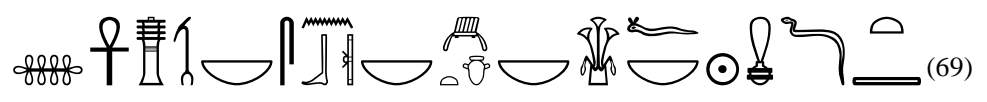

s3 'nh $\underline{d} d$ w3s nb snb 3wt-ib nb ḩ3.f nb mi R' $\underline{d} t$

'Every protection, all life, stability, and dominion, all health and all joy, surrounds him like Re forever ${ }^{\text {(70). }}$.

3.1.4.2. The text, which accompanies the scene of mowing grain in the version of the ritual on the east exterior girdle wall at Karnak (Fig. 3), can be read as follows:

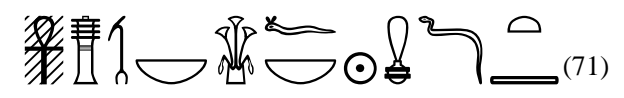

(diw 'nh) $\underline{d} d$ wzs $n b$ ḩ3.f $n b$ mj $R^{\prime} \underline{d} t$

'Every (life), stability, and dominion (have been given), all surrounds him like Re forever'.

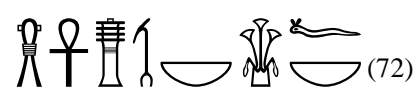

s3 'nh $\underline{d} d$ w3s nb h. h. $\mathrm{f} n b$

'Every protection, life, stability, and dominion, all surrounds him'.

\subsection{Ritual of Cutting Grain in the Festival of God Min:}

The ritualistic event of cutting grain, which is portrayed on the second pylon of the Ramesseum (Fig. 4) ${ }^{(73)}$ and in the second court in the Great Temple of Medinet Habu (Fig. 5) ${ }^{(74)}$, is an episode in the festival of god Min, which happened there. In this episode, the god has no explicit physical attendance in his traditional form as an ithyphallic god but he is embodied in the form of a bull crowned with two feathers and a sun-disc between two horns and the accompanying inscriptions give obvious indication to him. Two kings participate in these versions of the ritual of cutting grain including King Ramesses II at the Ramesseum and King Ramesses III in the second court at Medinet Habu. The iconography of the ritual in the Ramesseum and the version of the second court at Medinet Habu is arranged in exactly the same way on each of the two copies. The arrangement of the scenes of the ritual in these two versions runs as follows:

3.2.1. The king wears a light tunic or blouse and a long pointed skirt adorned with two cobras as well as the tail of the bull. His head is adorned with the ceremonial 
hprš-crown ${ }^{(75)}$. Facing the king is a priest hands him a tuft of freshly harvested ears and the king seizes them with his left hand, while with the right hand he prunes their stems and cuts them with a sickle carried by his right hand ${ }^{(76)}$.

3.2.2. The king is advanced by a white bull personifying the fertility god Min. Behind the bull there is a servant walking in the same direction and holding in his two hands a wreath raised to the face height ${ }^{(77)}$. Above the wreath-bearer, the queen is shown standing with her both arms folded over the middle of her chest ${ }^{(78)}$. Behind the queen and the wreath-bearer, the king is surmounted and protected by the divine falcon with half-open wings ${ }^{(79)}$.

3.2.3. The falcon is shown hovering above the king to protect him in the version of the ritual in the second court at Medinet Habu Temple ${ }^{(80)}$.

3.2.4. The accompanying inscription describes the event of cutting grain in details and it can be read as follows:

3.2.4.1. The text, which accompanies the scene of mowing grain in the version of the ritual in the Ramesseum (Fig. 4), can be read as follows:

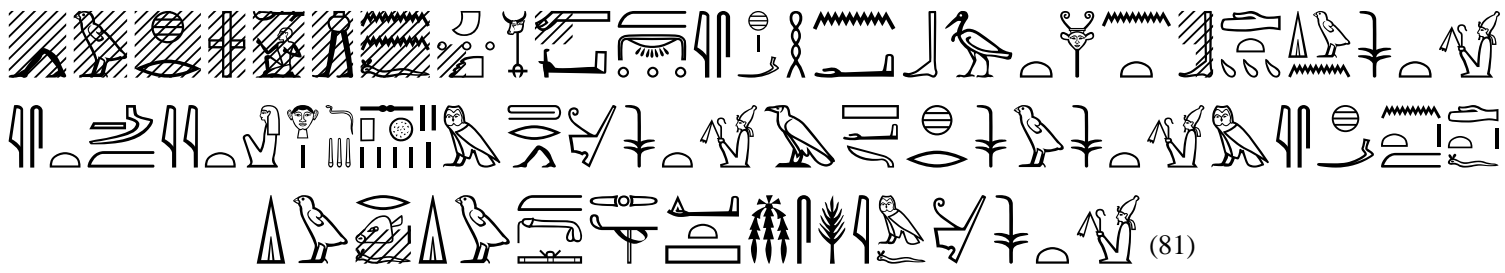

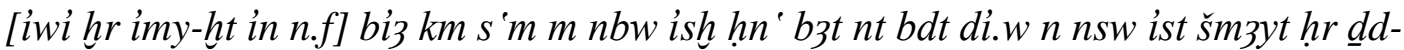
$m d w$ sp $7 m$ phr $n$ nsw $m$ š $d$ hr sw nsw $m$ ish nt(y) $m$ drt.f di.w r-hnt.f di.w $m$-b3h mnty dit šmsy m.f $n$ nsw

'[Also comes the member of the bodyguard; he brings for him (i.e. the king)] a sickle of black copper inlaid with gold, and a bushel of emmer, which are given to the king. Here the queen recites the formulas seven times while turning around the king. Then the king cuts it (the tuft) with the sickle that is in his hand. (The sheaf) is given to his nose, and laid in front of Min, and a corn from it is given to the king ${ }^{(82)}$.

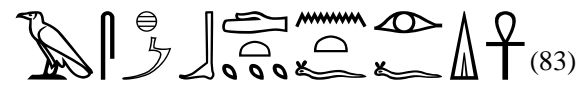

3sh bdt $n$ it.f iri.f di ' $n$ h

'Cutting grain for his father (so that) he may be given life'(84).

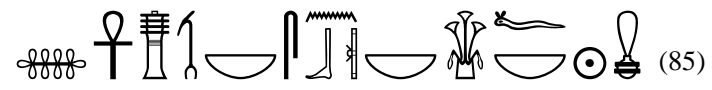

s3 'nh $\underline{d} d$ w3s nb snb nb ḩ3.f nb mi $R$ '

'Every protection, life, stability, dominion and all health (have been given), all surrounds him like Re'. 
3.2.4.2. The text, which accompanies the scene of harvesting grain in the version of the ritual in the second court at Medinet Habu Temple (Fig. 5), runs as follows:

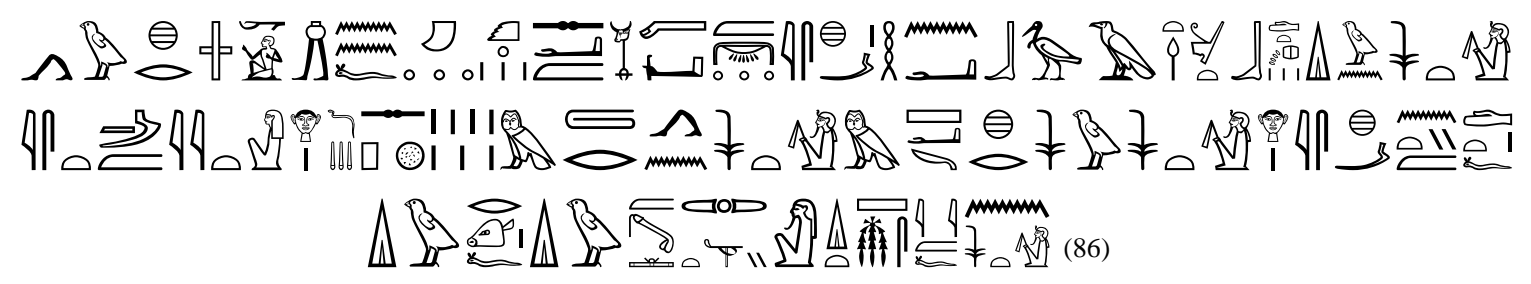

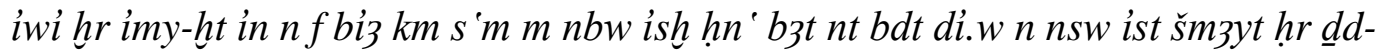
mdw sp $7 m$ phr $n$ nsw $m \check{s}^{\circ} d \underline{h r}$ sw nsw hr ish nty $m$ drt.f di.w r-fnd.f di.w m-b3h mnty dit šmsy m.f $n$ nsw

'Also comes the member of the bodyguard ${ }^{(87)}$; he brings for him (i.e. the king) a sickle of black copper inlaid with gold, and a bushel of emmer, which are given to the king. Here the queen recites the formulas seven times while turning around the king.

Then the king cuts it (i.e. the tuft) with the sickle that is in his hand. (The sheaf) is given to his nose, and laid in front of Min, and a corn from it is given to the king ${ }^{\prime(88)}$.

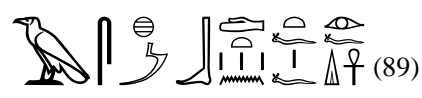

3sh bdt $n$ it.f iri.f di ' $n$ h

'Cutting grain for his father (so that) he may be given life'(90).

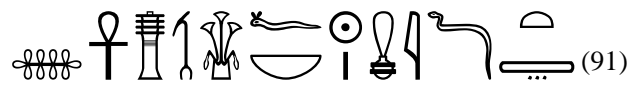

s3 'nh $\underline{d} d$ w3s h.j.f nb mi $R^{\prime} \underline{d} t$

'Every protection, life, stability, and dominion (have been given), all surrounds him like Re forever'.

\subsection{Ritual of Cutting Grain in the Presence of God Hapy:}

Side Room 26 in the Mortuary Temple of Ramesses III at Medinet Habu (Fig. 6) ${ }^{(92)}$ is the only space that shows an image of the vignette of Chapter 110 in the Book of the Dead representing the king while practicing the ritual of cutting grain in the Iaru Fields ${ }^{(93)}$. This unique version includes the characters arranged as follows:

3.3.1. The king is figured in the scene behind another figure representing him worshipping god Hapy. He wears a false beard, a short kilt, and the tail of the bull. He is crowned with the $h \underline{d} t$-White Crown of Lower Egypt. The King carries in his right hand a sickle and cuts sheaves of grain gathered by his right hand ${ }^{(94)}$.

3.3.2. God Hapy is portrayed sitting on the throne and wears the traditional headdress, curved false beard, and a short kilt with belt. Despite of appearing as a male god, he is figured with heavy and pendulous breasts and a large paunch ${ }^{(95)}$. He carries in his right hand two f $n h$-signs and in his left hand he holds the $\mathfrak{f}_{w 3 s-}$ 
scepter. Because of his embodiment of the water of the Nile river and of his annual inundation, he is adorned with an aquatic plant ${ }^{(96)}$.

3.3.3. The text that is written in the company of the scene (Fig. 6) runs as follows:

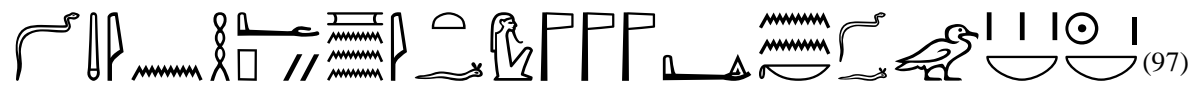

$\underline{d} d \mathrm{mdw}$ in Hзpy it ntrw di.n n.k $\underline{d} f_{3} w \mathrm{wb} r^{\circ} n b$

'Words spoken by Hapy, the father of the gods, I have given to you all the provisions every day'.

\section{Symbolism of Cutting Grain in the Ancient Egyptian Religion:}

The emmer wheat was one of the notable ancient Egyptian products and a crucial source for bread and beer in ancient Egypt ${ }^{(98)}$. There were several varieties and species of emmer wheat and barley cultivated in ancient Egypt ${ }^{(99)}$. The triticum dicoccum (Fig. 1) is the type of the glume emmer wheat that was reaped by the king in the ritual of cutting grain in the Theban Temples during the New Kingdom ${ }^{(100)}$. It was the only type of emmer cultivated in ancient Egypt since the Neolithic time at Fayum and down to late times and the Ptolemaic Period ${ }^{(101)}$. It is a type of wheat with a very dense, laterally compressed, and narrow ear ${ }^{(102)}$. During the New Kingdom ${ }^{(103)}$, the emmer became the most important cultivated cereal in Egypt and began to be used as a primary source for paying wages and taxes ${ }^{(104)}$. Additionally, grain was a common motif of Egyptian artwork throughout the different periods, suggesting that its growth was also a major focus in the ancient Egyptian religion.

The ancient Egyptians relied on the grain for more than just the production of the nourishment. They were creative in its use in their religious practices. In general, grain was used in ancient Egypt not only as human food but also for religious purposes ${ }^{(105)}$. There was an annual ritual performed by harvesters for cutting grain with the sickle and inscribed on the walls of the individual and royal tombs since the time of the Old Kingdom. In the private tombs of the Old Kingdom, a group of harvesters were usually depicted cutting the grain before the tomb owner, who participated in the event only as a supervisor ${ }^{(106)}$. The participation of the deceased as a harvester in the field started during the New Kingdom private tombs of Thebes ${ }^{(107)}$. This field is situated in the paradise. It is mentioned in spell 110 in the book of the dead, which deals with the entering and going forth from the necropolis and the uniting in the fields of reeds and offerings, where the justified dead will be able to plow, reap, eat, drink, make love, and do everything there as it is done on earth ${ }^{(108)}$.

In the New Kingdom Theban temples, the common participant in the ritual of cutting sheaves of grain was the king, who served in the event as the protagonist (Figs. 2-6). In this ritual, the king practiced his meaningful and responsible activity of harvesting in the presence of several fertiltiy gods. Consequntly, the king, who presided over this ceremony, naturally obtained the same divine favor of fertility. The grain was also the type of the crops found in important ritual scenes in the Iaru Fields in the afterlife. In the ritual of cutting sheaves of grain, the king acted as a royal harvester in his own fertile land in the earthly world and in the sacred Iaru-fields in the hereafter. The 
participation of the king in such an agrarian ritual in his life and after his death might allude to his control over abundant fields and tracts of cultivated lands including plentiful crops in the earthly and other worlds ${ }^{(109)}$.

The rite of the harvesting of the grain in the celestial world is quite often mentioned for the first time in the Pyramids Texts, such as in Utterance 667A (Spell §1936d) ${ }^{(110)}$ as one of the essential rites celebrated by the king $^{(111)}$. Thus, the scene of the ritual of cutting grain in the otherworld (Fig. 6), is the New Kingdom version of the so-called ssh.k-bdt $\theta$ in Utterance 461 (Spell \$874a) in the Pyramid Texts, which is the ritual of reaping the emmer by the deceased king to make his yearly sustenance and to secure his livelihood in the Fields of the Iaru ${ }^{(12)}$. In the earthly world, the king performed the ritual before god Amun-Re-Kamutef and in the pressence of god Min during the celebration of his festival. On the other hand, he practiced his work in the ritual in front of god Hapy in the otherworld. It seems clear that the three gods Amun-Re-Kamutef, Min, and Hapy were embodiments of the masculine principle and all of them acted as fertility gods in the ancient Egyptian pantheon. There was a close relationship between the three gods, in which both of gods Amun- $\operatorname{Re}^{(113)}$ and Hapy ${ }^{(114)}$ associated with the Nile and fertility and considered as the responsibles for bringing the flood, prosperity, and fertility to the Egyptian lands. As for the association between god Min and the Nile, it appeared very clear when painting his skin in the reliefs in black, as a symbol of the fertile soil of the Nile ${ }^{(115)}$.

The ${ }^{\circ}$ I I I bdt-grain that was clearly recorded to be cultivated in the versions of the ritual of cutting grains in the Ramesseum and in the second court in the Great Temple of Medinet Habu was one of the cultivated cereal crops in ancient Egypt that were specially associated with the concept of fertility, self-reproduction, and non perish $^{(116)}$. Thus, it was associated with the immortal cult of the sun-god Re and symbolized the victory of life over death ${ }^{(117)}$. This symbolism was expressed through the performing of the ritual of harvesting grain in the presence of the compsoite god Amun-Re-Kamutef, whose nature gathers between the characters of the creator gods Amun and Re and whose iconographical representation and functional form alludes to the ithyphalic form of Kamutef in reference to his fertility. Moreover, god Amun-Re was a self-generated god in the ancient Egyptian religion. In a hymn to god Amun-Re dating back to the New Kingdom and recorded on the Papyrus Leiden I 344, he came forth as self-generated $\operatorname{god}^{(118)}$. The self-renewal and self-germination of the grain was clearly apparent in small wrapped elaborate human mummies called 'Grain Mummies' or 'Corn Mummies, ${ }^{\text {(119) }}$ found in ancient Egypt in a number of cemeteries in Upper and Lower Egypt in the period from the Late New Kingdom or more likely the Saite-Late Period until the Roman Period ${ }^{(120)}$. Such mummies made of mud and contained wrapped figures ${ }^{(121)}$, usually in the shape of god Osiris and less commonly in the form of the composite god Ptah-Sokar-Osiris in addition to emmer grain or barley ${ }^{(122)}$. They functioned as guarantors for the rebirth of the dead in the otherworld. These mummies might be considered as divine models for the return to life, 
particualry that they closely connected to god Osiris. The revival of the inside grain will cause the rebirth of not only god Osiris but also of all the dead who identified with him $^{(123)}$. According to Wilfong ${ }^{(124)}$, the grain inside the mummy would grow selfly to create new life in the dead body and ensure the resurrection. This opinion is reignforced through the representing of the grain mummy with an erect penis as a symbol of the fertility of the deceased and the ability of the resurrection in the afterlife $^{(125)}$.

In this ritual, Kamutef was applied as a functional epithet associated with the name of god Amun-Re, who appeared therein as Amun-Re-Kamutef ${ }^{(126)}$. Apparently, god Min was considered as an independent deity and one of his functional titles was Kamutef ${ }^{(127)}$. God Min as Kamutef confirms that he gathered the essential unity of the divine father and the divine son in himself because he was a virile bull of his mother ${ }^{(128)}$, goddess Isis ${ }^{(129)}$, with whom he experienced his sexual vigor and impregnating power. The relationship between the two symbols of fertility ${ }^{(130)}$, god Amun-Re and god Min, was firmed at Thebes during the time of the New Kingdom through the fusion between them in the form of the composite gods ${ }^{\circ}$

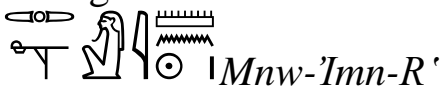

i.e.
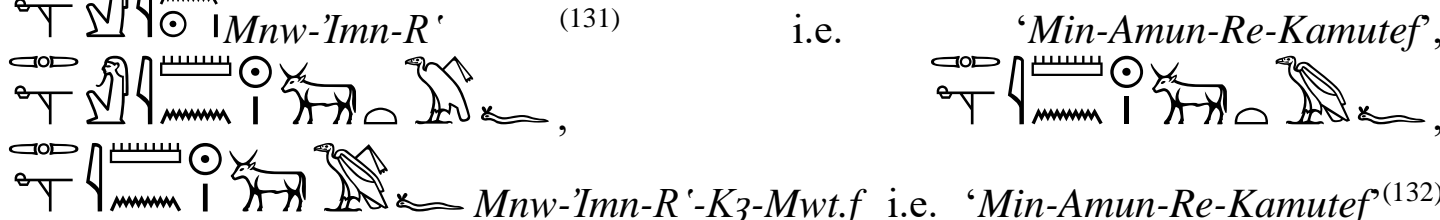

'Imn-R'-K3-Mwt.f i.e. 'Min-Amun-Re-Kamutef' ${ }^{\prime(132)}$
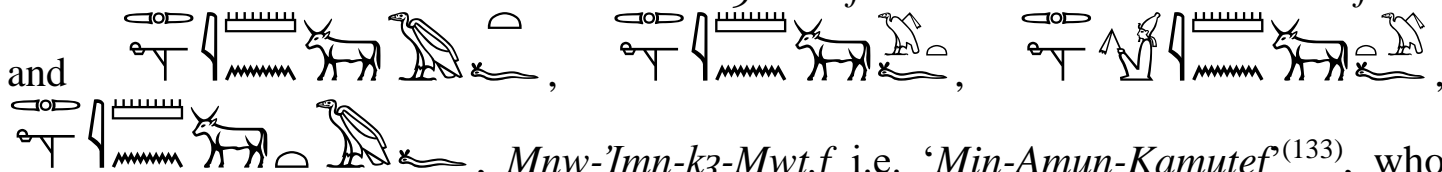

व

$12 \_, M n w-I m n-k 3-M w t . f$ i.e. 'Min-Amun-Kamutef' ${ }^{(133)}$, who was issued of the sun-god $\mathrm{Re}^{(134)}$. Even when the concerned god in the ritual was god Amun-Re in his form as Kamutef ${ }^{(135)}$, there was a connotation to the existence of the essence of the fertility god Min ${ }^{(136)}$, who was known in Coptos during the Middle Kingdom as Kamutef and who started his role as Kamutef at Karnak since the time of the Eighteenth Dynasty ${ }^{(137)}$.

In the iconography of the ritual of cutting sheaves of grain in the Theban temples, god Amun-Re-Kamutef was shown in the same form of god Min as an ithyphallic god standing on a pedestal with a flagellum in the raised hand and the crown of god Amun on his head ${ }^{(138)}$. Behind the god Amun-Ra-kamutef stands the plants of god Min as a clear declaration of the association between god Amun-Re and god Min. Additionally, god Amun-Re-Kamutef appeared in the second episode of the festival of god Min, in which he receives sacrifices ${ }^{(139)}$. Therefore, this ritual seems clearly to allude to the fact that at the moment of the harvesting and the cutting of the grain, the both fertile gods, Amun and Min, has completed the mystery of Kamutef again ${ }^{(140)}$. According to Lurson ${ }^{(141)}$, the monarchical ideology is therefore largely at the origin of the choice of ritual acts. It is the context, which can also explain the presence of gods Amun-Re-Kamutef, Min, and Hapy in such an agrarian ritual, having regard to their links with the kingship and fertility. 
In the religious sphere, the ritual of cutting a sheaf of wheat was one of the stages of the feast of the fertility-god Min. In the fifth episode of the festival of the harvest-god Min, the king cuts off a sheaf of grain in front of the shrine of god Min with a copper sickle covered with gold and presents it as a thanksgiving offer to the god and another ear of it is given to the king in turn ${ }^{(142)}$. Consequently, this ritual was performed to ensure the reproduction of the plant and the continuity of the annual harvest. It would be considered as a cultic regeneration of both the king and the land, in which not only the land has been benefited by the harvest in this rite but also the fertility of the king as well as his royal function and power of victory were reaffirmed and preserved ${ }^{(143)}$.

In fact, such an agricultural and vital ritual has three features concerned the divine character, the royal figure, and the land effectiveness. These three icons related to each other and all of them aimed to glorify the concept of the fertility of the god, the king, and the fecund land of Egypt ${ }^{(144)}$. According to Brunner-Traut ${ }^{(145)}$, the harvest ceremonies and the ceremony of the secession of the wheat has the sub-sense of repeatedly defeating the enemies of both the god and the king, according to the general symbolism of sacrifice ${ }^{(146)}$. Additionally, such offering ceremonies recall us with the human sacrifice, which was firstly attested during the First Dynasty ${ }^{(147)}$, and the so-called execration ritual which included specific formulae intended to ward off or destroy harmful entities and enemies and to drive the evil spirit before they had a chance to inflict harm on anyone ${ }^{(148)}$. The great offerings are considered as a substitute for the enemies, whom the deity would have massacred to overcome the evil power ${ }^{(149)}$. This opinion is supported through the preference of the using of the sickle rather than utilizing other methods of harvesting such as the uprooting or even reaping by hand in the ritual ${ }^{(150)}$. The sickle is a sharp weapon-like tool with a curved blade, so that its use in the ritual symbolizes the victory of life over evil. In this context, it is worthy to note that the utilizing of the sickle as the main tool in cutting the grain in a ritual related to the fertility of god Min and the destruction of the enemies may imply to the celestial nature of god Min. The heavenly character of god Min shows certain violence interpreting his use of the light-weapon as the majority of the other thunderbolt gods ${ }^{(151)}$. Moreover, the hymn that is engraved behind the king in the versions of the ritual in the temple of Medinet Habu and the Ramesseum and is recited by the lector priest, gives a direct evidence about the metaphorical implication of the ritual, which is the destruction of the enemies for the regeneration. This hymn, which is directed to god Min in his agricultural character in order to glorify his power and justification over his enemies in heaven and to ask him a full protection for the king against the evils, runs as follows:

$$
\begin{gathered}
h w s_{3}-R^{\prime} N m^{\prime} \text { ' ht } n b \underline{d} w m_{3} \text { - } h r w \text { Mnw } r \text { hftyw } m p t \\
\text { 'Protect King } N \text { against all bad thing(s), Min (who) is justified in front of the } \\
\text { enemies in the sky'(152). }
\end{gathered}
$$

According to Bleeker ${ }^{(153)}$, the harvest rite is mostly connected with the sacrificial rite or can be considered at the same time a sacrificial rite and the real meaning of this rite 
only becomes clear when one sees it in the light of the typical idea of sacrifice, namely the truth that man can only survive through a symbolic act. If taking into account the agrarian ritual of cutting sheaves of grain as a sacrificial ritual, the interpretation of the rite as a symbolic event of sacrificing the enemies will be more plausible. Consequently, offering the first sheaf of harvested wheat to the fertility-god and presenting a similar one to the king at the end of the ritual confirm their productivity power and allude to the symbolic character of the ritual, which is the human sacrifice that was hidden in the act of cutting the grain as a symbol of the enemies. Bleeker ${ }^{(154)}$ explained also this ritual as a cultic act. According to Lurson $^{(155)}$, this ritual has been interpreted as an agrarian rite and it has a close connection with the royal ideology and the proclamation of royal power. Therefore, the ritual takes on a political dimension with an allusion to the overcoming of the goodness over the evil and the destruction of the power of chaos and enemies. This

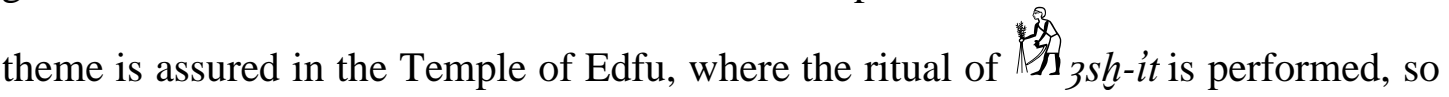
that the fertility-god Min granted the king the kingship in addition to the power of the two crowns and the superiority over the Two Lands ${ }^{(156)}$. The ritual of cutting grain supports the idea that each new king prefers to inaugurate his reign with the dramatical ceremony of a symbolic offering of a freshly harvested sheaf of wheat to the fertility-god Min as a significance of the starting of a new considerable and productive era ${ }^{(157)}$. The rite also realizes the victory of the divine realm and the royal life over the cosmic enemies through the representations of cutting grain by the weapon-like sickle of the king.

Grain was regarded as the symbol of the sacred power because it was the primary source of the nourishment of the community ${ }^{(158)}$. It began to be recorded as a funerary offering in the offering lists during the Fifth Dynasty ${ }^{(159)}$. In the sixth division/ seventh hour of night in the Book of the Gates, there are two contradictory themes representing the punishment of the damned and the rewarding of the justified ${ }^{(160)}$. Some of the justified dead stand before large ears of grain and others are shown as a group of sickle-bearers reaping the grain in the eternal field as an indication that they can enjoy its sacrificial food of grain as offerings ${ }^{(161)}$. At the middle register, stands a great punishment scene on seven poles of torture representing the enemies of the sungod Re, god Osiris, and the great ennead of Heliopolis ${ }^{(162)}$. In the same vein, the leitmotif in the ritual of cutting sheaves of grain in the Theban temples is the rewarding of the king and the god with regenerative offerings from the crops of the fertile land as an insurance of their fertility power on one hand and the defeating of their enemies by the sickle on the other hand. The sickle would had emblematic use in the ritual. Its use confirmed realistically that the grain was reaped and the king was given an offering of it in order to be able to regenerate and to obtain his power. Additionally, it referred symbolically to the superiority of the king and the god over the adversaries and confirmed their destruction. Thus, the whole theme of the ritual symbolizes the eternal victorious of the god and the king and their regenerative power over their enemies. Moreover, the fruitful and fertilizing virtues of the king and the fertility gods $\mathrm{Min}^{(163)}$, Amun-Re-Kamutef, and Hapy are glorified in this ritual. According to Fairman ${ }^{(164)}$, the trampling of the enemy under the foot of the king is 
equated with the scattering of the grain and treading upon it at the harvest festival. Similarly, when the king reaps the sheaf of grain in the presence of the fertile gods, this is regarded not only as the divine and royal victory of the god and the king over their enemies but also a confirmation of their fertility, regeneration, and power. The similarity between the enemies and the grain is often attested in the Temple of $\mathrm{Edfu}^{(165)}$, where the enemies were threshed like the grain by god Horus in his form as the unifier of the two lands after smiting them as follows:

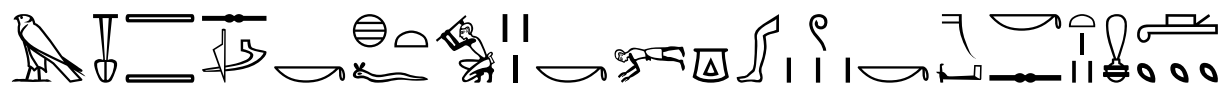

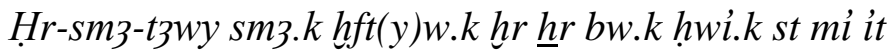

'Horus-sema-tawy, you smite your enemies who have fallen under your feet, you thresh them like grain',(166).

In the Temple of Edfu, the ritual of cutting grain is entitled it is perfomed by the king before god Horus-sema-tawy (Fig. 7). This terminology is

determined by the hieroglyph of a sharp-bladed knife $\precsim$; an implication which alludes to a probable violence. Moreover, the accompanying formula implies to the enjoying of the otherworld as a result of walkig upon the fertile land and cutting its crops as a symbol of the destroying of the enemies and it can be reads as follows:

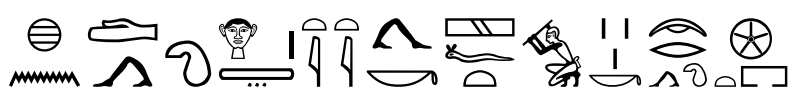

hnd.k hr t3 titi.k hftyw.k spr.kdzt

'(When) you tread upon the land, you trample your enemies, you reach the underworld' ${ }^{(167)}$.

It seems that the cereals symbolize the enemies of the king and with their trampling or reaping he can enjoy his rebirth and eternal life. Accordingly, both of the foes and the grain have the same evil symbolism. This matter is confirmed by Wilson ${ }^{(168)}$, who suggested that the cutting of the cereal symbolizes the destruction of enemies. In this context, the ear of wheat dies under the weapon-like sickle just like the enemies when they were usually perished under the weaponry of the $\operatorname{king}^{(169)}$. On the other hand, the ritual of cutting grain marks the giving of the life power to the king particularly that it is regarded as the bearer of a sacred power because it contains the food on which the life of the human beings depends. Furthermore, the offering of the sheaf of grain to the king alludes to the taking of the life force of the grain by him and confirms his continuity. Thus, the ritual of harvesting sheaves of grain forms by that way a separate line between life and death and refers to the divine and royal fertility and eternity. Through the death of the enemies-like grain, the king receives life and regeneration ${ }^{(170)}$. This concept was recorded in a verse in the accompanying text of the versions of the ritual in the Ramesseum and on the east wall of the second court in the great temple of Medinet Habu as follows: 


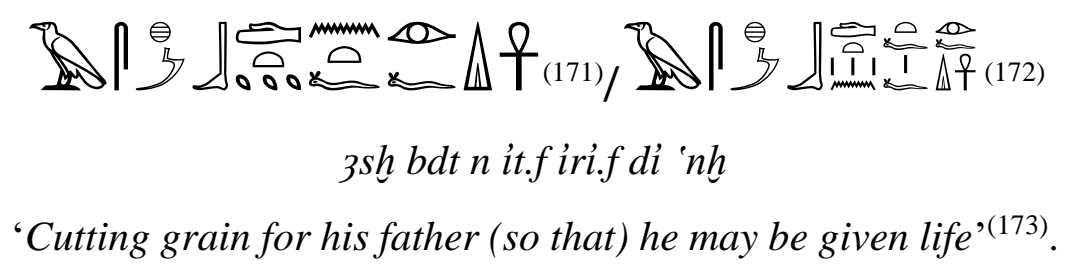

The self-germination of the grain symbolizes the fertility and resurrection. This practice referred to the religious function of the grain as one of the sacred cereals in ancient Egypt that reveals the idea of renewing the life and youth of both the deity and the king.

\section{Results}

According to table no. (1), the following points could be concluded in the topic in question:

\subsection{Based on their date, the scenes of the ritual could be concluded as follows:}

5.1.1. There are five scenes representing the ritual of cuttin sheaves of grain before a number of fertile deities in the Theban temples (Figs. 2-6). Out of the five scenes, there are three scenes dating back to the Ninteenth Dynasty, from the reign of King Ramesses II (Figs. 2-4). On the other hand, there are only two scenes from the Twentieth Dynasty, particularly from the reign of King Ramesses III (Figs. 5-6).

5.1.2. King Ramesses II was the most common Ramesseide king being depicted cutting sheaves of grain in the presence of a certin fertility god (Figs. 2-4). He was depicted in the oldest two scenes of the ritual in front of god Amun-Re-Kamutef in the Great Temple of Amun-Re at Karnak (Figs. 2-3). Additionally, the same king was represented practicing the ritual during the festival of coming forth of god Min in a solemn scene in the Ramesseum Temple (Fig. 4). King Ramesses III was depicted participating in the ritual in two scenes in his Mortuary Temple at Medinet Habu (Figs. 5-6). In one of the scenes at Medinet Habu Temple, King Ramesses III was shown cutting the grain in the fields during the celebration of the festival of the departure of god Min (Fig. 5). King Ramesses III was shown in another scene in Medinet Habu Temple in the Fields of the Iaru according to Chapter 110 in the Book of the Dead (Fig. 6). He is the only king depicted practicing the ritual of the cutting of the sheaves of grain in the Iaru-Fields.

5.1.3. After the reign of King Ramesses III, the scenes of the ritual of cutting sheaves of grain were no more attested in the Theban temples. Consequently, the ritual of cutting sheaves of grain was participated by the king as a separate ritual act only during the reign of King Ramesses II and as an eternal event in the Iaru-Fields only during the reign of King Ramesses III. However, the same ritual was celebrated as a cultic episode in the festival of god Min during the reigns of King Ramesses II and King Ramesses III. Noteworthy is that the ideology of the ritual has been changed from the Nineteenth Dynasty to the Twentieth Dynasty. This modification can be traced in the changing of the ritual from being a common ritual perfomed by the dead in the private tombs during the coregency between Kings Ramesses II and Sety I to be a more sacred ritual practiced by the king in the Theban Temples during the reigns of kings Ramesses II and Ramesses III ${ }^{(174)}$. This cultic change is probably because of 
the increasing of the religious tendency of King Ramesses II that led him to build prodigious amount of the religious buildings during his reign.

\subsection{The location of the scenes of the ritual provides further reference to their religious symbolism and importance as follows:}

The two scenes of God Amun-Re-Kamutef are located in the same temple of god Amun-Re at Karnak (Figs. 2-3). The two scenes of the festival of God Min are situated in two different locations; one in the Ramesseum Temple (Fig. 4) and another in the Temple of Medinet Habu (Fig. 5), where the scene of god Hapy is also located (Fig. 6). The ritual of cutting sheaves of grain was often represented in the Theban temples in the inner parts of the temple revealing its sacred symbolism especially during the reign of King Ramesses III. For example, one of the two scenes of the ritual in the temple of god Amun-Re at Karnak is located in the interior of the hypostyle hall (Fig. 2), which is an interior and very sacred space. On the other hand, the second scene of the ritual in the temple of god Amun-Re at Karnak is portrayed on the exterior girdle wall (Fig. 3), which encloses the entire rear portions of the sanctuary of the temple from the Fourth Pylon to the Festival Hall of King Thutmoses III $^{(175)}$. The inner face of the second pylon in the Ramesseum Temple (Fig. 4) and the second court in the Great Temple of Medinet Habu (Fig. 5) are consecrated for the iconographical representaion of the festival of god Min because of being sacred spaces related to the rebirth of the sun and the regeneration of the Osirid king respectively ${ }^{(176)}$. Noteworthy is that the latter two sacred locations confirm the regnerative character of the ritual. The ritual of cutting sheaves of grain was also represented once in side room 26 in the Great Temple of Medinet Habu (Fig. 6), which is one of the mortuary cult rooms adjoining the second hypostyle hall in the temple ${ }^{(177)}$.

\subsection{Concerning the fertile gods, who are depicted in the ritual, they are}

5.3.1. God Amun-Re-Kamutef, who appeared in two scenes in the temple of AmunRe at Karnak (Figs. 2-3). In these two scenes, King Ramesses II was the royal harvester and the main participant in the ritual. That means that he was the chief fertility deity in the ritual during the reign of King Ramesses II in the Nineteenth Dynasty. God Amun in his form as Kamutef served as a creator-god in a hymn to King Ramesses V written on the papyrus P. Chester Beatty I, Verso, Section B as follows ${ }^{(178)}$ :

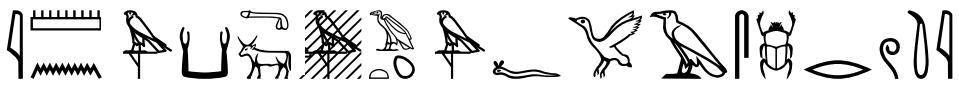

Imn k3-mwt.fp3 shpr ti

'Amun Kamutef, who gave birth to you'.

The identification of god Amun-Re as Kamutef in the ritual was a reflection of the fertility of the detiy and his triumph over death; a concept that integrates with the connotation of cutting grain as a symbol of the triumph over the enemies and their destruction. In his two versions of the ritual, god Amun-Re-Kamutef assumed the traditional form of god Min, in which he appears in the form of a masculine body 
bandaged in shroud with an erected penis, which symbolizs his fertility and procreative power in addition to his sexual and divine creation energy ${ }^{(179)}$. He holds in his raised hand the $n$ hh-flail of authority ${ }^{(180)}$. According to Kees ${ }^{(181)}$, the upraised hand is one of the properities of god Horus of Libya. In this context, it is worthy to mention the assimilation between god Min, who is personified in two versions of the ritual in the form of god Amun-Re-Kamutef (Figs. 2-3), and god Horus in the form of the composite god Min-Horus-Nakht, who is known for his procreative power and who is a form of the victorious god Hours and recalls his victory over his enemy, the evil-god Seth ${ }^{(182)}$. Moreover, Ogdon ${ }^{(183)}$ assumed that god Min was not only a fertility god but also a protector deity and had a protective ability towards evil and enemies that was highly influenced by the idnetifcation of god Min with god Horus-Nakht. Thus, the incarnation of god Min in the form of his equivalent, god Amun-ReKamutef, in the versions of the ritual at Karnak (Figs. 2-3) alludes to the generative ability of the latter in addition to his aggressive character as well. Most probably, the $\mathbb{A}$

$n h$ h-flail in the upraised hand of the god in the ritual of the cutting of the sheaves of grain is a replacement of the weapons in the war particularly that the ritual has a connotation of the victory of the king and the god over their enemies ${ }^{(184)}$. In the ritual of cutting sheaves of grain in the Theban temples, god Amun-Re-Kamutef also wears a crown with two feathers and a a ribbon around his forehead trailing to the ground. In Spell 335 in the Coffin Texts ${ }^{(185)}$, the two long feathers are personified in the form of god Horus as the protector and savior of his father. Consequently, the two plumes above the head of god Amun-Re-Kamutef in the ritual of cutting sheaves of grain in the Theban temples symbolize god Horus and confirm the protective power of the wearer and his ability to save himself from the evils. In the version of the ritual, which is depicted on the girdle wall of the Great Temple of Amun-Re at Karnak, the god stands on a high base taking the form of the hieroglyphic sign $m_{3}{ }^{\prime} t \Longleftarrow$. Such an assimilation confirms the main aim of the ritual in protecting the equilibrium of the universe and the ensuring of the victory of the truth, which is personified in the figures of the king and god, over the evil that is embodied in the form of the grain harvested by the royal sickle in the presence of the god ${ }^{(186)}$. Although the reliefs of the ritual, which include representations of god Amun-Re-Kamutef, are not painted, the skin of god Amun was usually painted either dark blue because of being a cosmic creator god or black in reference to the fertile soil of the Nile and as a symbol of his fertility and procreative power ${ }^{(187)}$. Behind the god stands a shrine heaped with two lettuce plants and a double flower with a long stem $^{(188)}$, probably symbolizing Upper and Lower Egypt and referring to the worshipping of the god all over Egypt and the kingship of the king over the two lands ${ }^{(189)}$. The ancient Egyptians viewed the lettuce as a kind of the plants that secrete white and milky fluid symbolizing the semen and probably stimulating the sexual desire ${ }^{(190)}$. The myth of the struggle between god Horus and god Seth confirms the same belief, in which the lettuce plant was believed to be an ancient aphrodisiac and it was utilized in the legend as a tool used to submit god Seth to the sexual power of god Horus ${ }^{(191)}$. Consequently, we must conceive the 
existence of the lettuce in the scenes of the ritual as a sexual reference to the fertility of the participated $\operatorname{god}^{(192)}$.

5.3.2. God Min, who was not depicted in his traditional form in the ritual, but there are two scenes belong to the festival of god Min (Figs. 4-5). King Ramesses II partiticaped in the ritual in the oldest of these two scenes (Fig. 4) and King Ramesses III was the protagonist in the latest one (Fig. 5). In these two scenes ${ }^{(193)}$, the king is advanced by a white bull probably personifying the spirit of the grain and appearing as the cultic representative of the fertility-god Min, to whom the harvested sheaf of grain would be introduced as an offering ${ }^{(194)}$.

5.3.3. God Hapy, who appeared in the ritual in a solemn scene in the presence of King Ramesses III (Fig. 6). In this unique version of the ritual, the king played the main role and practiced the act of cutting sheaves of grain in the Iaru-Field before god Hapy. God Hapy, was the god of the Nile and its annual flood in the ancient Egyptian religion $^{(195)}$. His participation in the ritual of the cutting of the grain as a personification of the concept of the prosperity and the fertility of the Nile is obviously plausible. There is a direct and strong asssociation between god Hapy and the Iaru-Fields particularly that the both are rich, refer to the bundance of the water, and symbolize fertility ${ }^{(196)}$. God Hapy serves in the ritual as an embodiment of the Nile and the Iaru-Field is viewed as a copy of the Nile valley ${ }^{(197)}$. Thus, the representation of god Hapy in the Iaru-Field in the version of the ritual of the cutting of the grain in Medinet Habu Temple symbolizes the existence and importance of the Nile in the fertile area of the Iaru-Fields and refers to his role in enliving the dead land owing to his fertility; which is the same aim of the ritual.

\subsection{Based on their connection with the fertility concept, other deities began to share the fertility god Min in a ritual related to the divine productivity as follows:}

There are two other deities, rather than the chief fertility god Min, witnessed the ritual of cutting sheaves of grain by the Egyptian king; a new tradition that appeared in the Theban temples as early as the reign of King Ramesses II. Thus, it seems clear that the ancient Egyptians became more flexible in depicting god Amun-Min-Kamutef (Figs. 2-3) and god Hapy (Fig. 6) as primary fertililty gods in the Great Temple of god Amun-Re at Karnak and in the Great Temple of Medinet Habu, where they replaced god Min therein and were given his same productive position in the Ramesseum and Medinet Habu temples (Figs. 4-5).

\subsection{With regard to the representation of the gods and the kings in the ritual, they are portrayed as follows: \\ With the exception of god Min, who is not portrayed personally, two gods and two kings are depicted in the ritual including god Amun-Re-Kamutef and god Hapy in addition to King Ramesses II and King Ramesses III.}

5.5.1. The Gods are represented as follows:

5.5.1.1. God Amun-Re-kamutef is shown in two scenes of the ritual at Karnak (Figs. 2-3). His two representation on the west interior wall of the hypostyle hall in the Great Temple of Amun-Re (Fig. 2) and on the east exterior girdle wall of the Great 
Temple of Amun-Re (Fig. 3) are mirror images to each other. In each of these two scenes, he appears in the same manner as god Min as an ithyphallic-god as a personification of the masculine principle and with a $\mathbb{N h h}_{n}$-flail as a symbol of his divine authority ${ }^{(198)}$. In this context it isworthy to note that as early as the Archaic Period, god Min served as a protective god of the grains and with his raised $\mathbb{n h h}_{n \text { - }}$ scourge he protected threshed grain from the birds and animals that want to take them away ${ }^{(199)}$.

5.5.1.2. In his solemn appearance in the ritual, god Hapy is represented in Room 26 in the great temple of Medinet Habu (Fig. 6) as an embodiment of the annual inundation of the Nile and of the natural fertility ${ }^{(200)}$. He appears sitting on the throne of the IaruFields with pendulous breasts and a large stomach as a symbol of the abundance and fertility of the water of the Nile ${ }^{(201)}$.

5.5.2. As for the portrayed kings in the ritual, their figures can be concluded as follows:

5.5.2.1. Their figures are similar to a great extent and appear facing the portrayed gods.

5.5.2.2. The king was always depicted grasping a handful of high cereal stems by one hand and cutting the straw below his other hand. Similarly, the harvesters in the wall scenes in the tombs of the individuals, are often shown in the same position as illustrated in the Tombs of Paheri at El-Kab and Mereruka at Saqqara ${ }^{(202)}$.

5.5.2.3. The positions of the hands and legs of the king as a reaper are identical in all the versions of the ritual.

5.5.2.4. In all the versions of the ritual, except only for the version of room 26 in the Great Temple of Medinet Habu, the king is not significantly leaning and have a straight or almost straight torso. The inclination of the king as a reaper in the ritual appears obviously only in the unique version of the ritual, which takes place in the Iaru-Fields and portrayed in Room 26 in the Great Temple of Medinet Habu (Fig. 6).

5.5.2.5. In all the versions of the ritual, the royal peasant was about to cut a sheaf of grain by a sharp sickle. The portrayed king carry the sickle in one hand and cut a sheaf of grain grasped by the other hand. The king always holds his sickle in his right hand and grasps with his left hand the few stems that he wants to cut with a single stroke of the cutting edge of his sickle. The king passes his left hand behind the stems and folds his fingers forward over the quantity of stems he wished to cut. The right arm, which grasps the sickle, is often extended forward with no bent, except in the versions of the hypostyle hall in the Great Temple of Amun-Re at Karnak (Fig. 2) and Room 26 in the Great Temple of Medinet Habu (Fig. 6), where the right arm of the king is extended and bent at the elbow. The left hand, which holds the stems, is always placed higher than the right hand, which carries the sickle, while still being close enough to it so that the stems in the right hand could be easily cut ${ }^{(203)}$. Moreover, the left arm is often deviated further from the vertical except only in the 
version of Room 26 in the Great Temple of Medinet Habu (Fig. 6), in which the left arm of the king is extended with no oblique movement. We can see the fingers of the left hand and the back of the right hand in all the scenes with the exception of the versions of the hypostyle hall in the Great Temple of Amun-Re at Karnak (Fig. 2) and Room 26 in the Great Temple of Medinet Habu (Fig. 6), where the contrary occurred.

5.5.2.6. The feet of the harvester king are regularly placed flat on the ground. Moreover, one of the legs of the king is always advanced one step forward to create a more realism and as an indication of his movement ${ }^{(204)}$, so that the king is represented in motion, walking on spaced legs towards the sheaves of grain during the performing of the ritual.

5.5.2.7. In the version of the ritual on the exterior girdle wall at Karnak (Fig. 3 ), in the Ramesseum (Fig. 4), and in the second court in Medinet Habu Temple (Fig. 5),

Kings Ramesses II and Ramesses III appear formal and wear the ceremonial hprš-Blue Crown adroned by the uraeus as a guarantor of the royalty ${ }^{(205)}$. The choice of the Blue Crown fits very well with the depicted event of cutting sheaves of grain. Several scholars viewed the Blue Crown as a symbol of the coronation and the legitimate succession to the throne of Egypt ${ }^{(206)}$. It was originated during the Second Intermediate Period, when there was a great need to emphasize the right of the succession to the throne and the victory of the legitimate king over his enemies, which is the same purpose of the ritual of cutting sheaves of grain by the $\mathrm{king}^{(207)}$. Noteworthy is also that the blue color of the Blue Crown symbolizes the fertility, birth, rebirth, and life and recalls the fertility of the water of the Nile and all this connotations fit well with the main significance of the ritual of cutting sheaves of grain in the Theban Temples ${ }^{(208)}$. As for the uraeus that adorns the crown, it is ready to eject fire towards the enemies of the king to protect him $^{(209)}$.

5.5.2.8. The kings are dressed in a light tunic or blouse and a long pointed skirt as well as the ceremonial tail of the bull as a symbol of the superhuman power ${ }^{(210)}$. The figures of Kings Ramesses II and Ramesses III on the second pylon in the Ramesseum Temple (Fig. 4) and on the second court in the great temple of Medinet Habu (Fig. 5) are completely identical. On the other hand, King Ramesses II is pictured in the version of the exterior girdle wall at Karnak (Fig. 3) without the two cobras that decorate and protect the kilt of the kings in the scenes of the ritual at Ramesseum (Fig. 4) and the second court in the great temple of Medinet Habu (Fig. 5). On the west interior wall of the hypostyle hall in the Great Temple of Amun-Re at Karnak (Fig. 2), King Ramesses II wears the same garment with which he appears in the version of the exterior girdle wall at Karnak (Fig. 3), but his head appears quite formal and is surmounted with a headdress protected by the uraeus. In the version of the ritual in Room 26 in the great temple of Medinet Habu, King Ramesses III is shown in the royal regalia and wears the $h \underline{d} t$-White Crown of Upper Egypt and the traditional tail of the bull ${ }^{(211)}$. 


\subsection{As for the shape of the grain cut in the ritual, it could be concluded as follows:}

5.6.1. The grain in the ritual are spikes or ears of cultivated awned emmer wheat and appears in the form of a bundle of grain stalks laid lengthwise and tied together. The fields in the ritual occupied by a simple succession of sheaves with ears and stems detailed with great care. The ears are at approximately equal distances from each other and the spaces between them are completely empty. The king bows slightly forward to cut the sheaves of grain by a sickle held by his right hand.

5.6.2. Out of the five versions representing the ritual of cutting sheaves of grain in the Theban temples, there are only two scenes depicting the ears of emmer grain plain of spikes in the hypostyle hall in the Temple of Amun-Re at Karnak (Fig. 2) and in the Ramesseum Temple (Fig. 4). In these two versions, neither the tufts of ears nor the stems are detailed, and the sheaves themselves are barely recognizable. Noteworthy is that such shorthand in the shape of some sheaves portrayed in the ritual during the reign of King Ramesses II reveals the ritualistic importance not the decorative function of this type of emmer grain and does not appear during the reign of King Ramesses III.

5.6.3. In the versions of the hypostyle hall in the Temple of Amun-Re at Karnak (Fig. 2) and Room 26 in the Great Temple of Medinet Habu (Fig. 6), ears of grain reaching to the ground level occupy the fields. On the other hand, in the rest of the versions on the girdle wall at Karnak (Fig. 3), in the Ramesseum (Fig. 4), and in the second court in Medinet Habu Temple (Fig. 5), the stems of the grain are raised from the ground level and appear above the advanced foot of the king. The height of either the standing ears and that of the cut stems, compared to the height of the standing king, does not vary greatly from one version of the ritual to another.

5.6.4. Generally, the harvested cereals are bound into sheaves and the height of the cut is slightly variable. On the other hand, the reaped grain were not bound into sheaves but rather it was only harvested in the form of ears only in the version of the ritual on the north wall of Room 26 in the great temple of Medinet Habu (Fig. 6).

5.6.5. The king always cuts the ears of the grain at a variable distance, but always quite large from the ground, which avoided him to tire by bending excessively ${ }^{(212)}$. The king seizes the upper part of the ears of the grain with his left hand, while with the right hand he prunes the lower part of their stems and equalizes them with a sickle so as to transform them into a presentable sheaf through transforming the rough and irregular tuft into a neat sheaf as was interpreted by Gauthier ${ }^{(213)}$.

\subsection{About the shape of the sickle used in the cutting of the grain in the ritual, they are:}

5.7.1. The ceremonial sickle in the ritual is a single-handed agricultural tool taking the shape of a reaping hook, designed with a curved blade. It was made of gilded black copper. It is ceremonially used for harvesting and reaping grain crops in a ritual related to the divine and royal fertility in the Theban temples of Karnak, Ramesseum, and Medinet Habu. In all the scenes of the ritual, the king is shown carrying his sickle in his right hand and uses it in cutting sheaves of grain grasped by his left hand. By 
the end of the Prehistoric Period, the copper has been used in the production of the tools and weapons ${ }^{(214)}$.

5.7.2. The black color has a great symbolism in the ancient Egyptian religion. It was the color of the silt left by the annual inundation of the Nile. According to the ancient Egyptian beliefs, the black silt was the source of the life. In the ancient Egyptian language, 'black' is called $\mathrm{km}^{(215)}$, the same term was also used in reference to the 'dark colored grain'(216) that was called $\mathrm{km}^{(217)}$. Accordingly, black is not only the color of the sickle that was used in the ritual of mowing of sheaves of grain but also it has a religious symbolism. It symbolizes fertility, life-giving, and resurrection because of the strong relation between the grain and the black color that contributed in the cultivatig of that kind of dark colored emmer. The using of a black sickle in the ritual of cutting sheaves of grain in the festival of god Min confirms the association between the black color of fertility and god Min. God Min was sometimes depicted with a black face since the Middle Kingdom ${ }^{(218)}$, as a symbol of his reproductive power ${ }^{(219)}$. Thus, the black sickle and the black face of god Min share the same energy of creation, regeneration, and fertility.

5.7.3. It is also worthy to note that the ancient Egyptians practiced the inlaying of the copper works with gold in a great scale ${ }^{(22)}$. It seems that there is an association between the copper and the emmer particularly that a sack of usually cost $1 d b n$ of copper during the Eighteenth and Nineteenth dynasties ${ }^{(221)}$. The employing of the gold in inlaying the main tool that was used in a ritual relating to the harvesting of the grain is so plausible and evokes a symbolic meaning. In the ancient

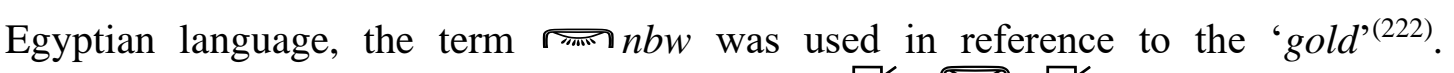
ט

Additionally, the same pronunciation $n b w \sqrt{m \times 1} 000 / 000000$ was also used as a designation of the ' $\operatorname{grain}^{(223)}$ and in reference to the figure of god Osiris kneaded from the grain in the Temple of Osiris at Dendera from the Greek Period ${ }^{(224)}$.

5.7.4. Bleeker ${ }^{(225)}$ interpreted the ritual as an act of harvest performed by the king in order to neutralize the dangerous sanctity of the grain and bring its vitality into the realm of his people. This interpretation characterizes the rendering of the sheaves of grain ineffective or harmless by applying an opposite force, which is the royal sickle in this case. All these explanations makes the context of the royal fertility clear. The king appears in the ritual as a savior, whose main responsibility is to save the humanity from the probable dangers of the enemies of the cosmos in addition to guarantee a decent life to his nation. He is the only warrantor of the continuity of the life in his country and this ritual is considered as a confirmation of his fertility and power

\subsection{As for the texts that accompany the scenes of the ritual, they support its main aim which is the fertility as follows:}


The accompanying texts of the ritual shared the same reward to the king through giving him life, protection, stability, dominion, health, joy, kingship, lifetime of Re, years of Atum, millions of years forever, and all the provisions because of his practcing as a harvester in the earthly and other worlds in a ritual related to the fertility. The texts can be detailed traced as follows:

5.8.1. The accompanying text to the scene of the ritual in the hypostyle hall of the Temple of Amun at Karnak (Fig. 2), gives a direct indication about the giving of the protection, stability, dominion, health, joy, kingship, lifetime of Re, years of Atum, all joy, and millions of years forever to the king ${ }^{(226)}$. Morover, the endless putting of the flat lands and the hill countries under the control of the king are also recorded in the accompanying texts.

5.8.2. In the version of the ritual on the girdle wall at Karnak (Fig. 3), the king was granted every protection, life, stability, and dominion because of performing the ritual $^{(227)}$. In the versions of the Ramesseum (Fig. 4) and the second court in Medinet Habu Temple (Fig. 5), the king granted health as well.

5.8.3. The accompanying texts of the ritual in the Ramesseum (Fig. 4) and in the version of the second court in Medinet Habu Temple (Fig. 5) are arranged in exactly the same way in each of the two copies. The written texts in these two versions are similar and give the only direct explanation of the ritual under the title \} 3 年

- 3sh-bdt i.e. 'Cutting grain'(230) Additionally, these texts give the clearest reference about the steps of performing the ritual and also confirm that the main aim of the ritual is to secure the life of the king in order to ensure his fertility ${ }^{(231)}$. The steps of the ritual in the Ramessem and in the second court in the temple of Medinet Habu run as follows: At first, the guardian of the king prepares a sickle made out of black copper inlaid with gold. Then, he gives it to the king together with an ear of emmer. At that time, the queen plays a great role while turning around the king, in which she recites several formulas seven times. After that, the king uses the sickle in cutting the tufts of emmer. After cutting the sheaves of grain, a corn from it is given to the king and the rest is presented to god Min as an offering ${ }^{(232)}$. The wife of the king is the only female participated in the ritual $^{(233)}$. Owing to the concept of Kamutef in the ancient Egyptian religion as a functional epithet associated several gods, such as god Amun-Re, it alludes to the process of impregnating his own mother by himself and the self-begotten or selfcreation of himself ${ }^{(234)}$. Jacobsohn ${ }^{(235)}$ preferred the interpretation of a mother mating in the festival of the fertility-god Min. So that, the presence of the queen in the ritual might refers to the royal wife and ideologically to the both women; mother and wife, as a fusion of the two women in one body, and the existence of the double role represented by the god as a father and a son at the same time.

According to the accompanying texts, the king mows the grain for his father and offers a sheaf of it to him. In turn, the father god receives it and thanks him by giving him an ear of it, as an indication that he may be given life ${ }^{(236)}$. According to Gauthier ${ }^{(237)}$, the king acts here as the representative and living embodiment of god Horus on the Egyptian throne, and the word 'father' here designate god Osiris, the 
father of god Horus and of the king in turn, and not god Min as one might think. The concept of the divine fertility is primarily assured through the death of god Osiris, which led god Horus to ascend the throne of Egypt ${ }^{(238)}$. This myth of ascension indicates the fertility of the father on one hand and ensures the fecundity Egyptian land on the other hand. Whether the word 'father' here refer to god Osiris or to god Min, it is worthy to note that there was an association between god Min and god Osiris since the time of the Middle Kingdom, when god Min was worshipped as the consort of goddess Isis and the father of god Horus, just like god Osiris ${ }^{(239)}$. One of the most remarkable notes in the texts which accompany the scenes of the ritual at the Ramesseum (Fig. 4) and Medinet Habu (Fig. 5) is the reciting of a sacred formula seven times by the queen. In the ancient Egyptian religion, number seven was not only a symbolic number but also a sacred one. It was considered as a divine number and related to several deities, such as the sun-god Re and god Osiris. Mythically, the sun-god Re had seven souls ${ }^{(240)}$. Number seven also had a strong connection to the birth of god Osiris, who spent a period of seven days in the womb of goddess Nut before begotten him $^{(241)}$. In ancient Egypt, number seven was a symbolic number and it was the symbol of perfection, effectiveness, completeness, and the sustainable universal powers ${ }^{(242)}$. In the Myths, number seven is always related to the victory of the sun-god Re over his archenemy Apophis, particularly that the seventh hour of the night in the Book of the Amdaut represents the hour of the solar triumph over the chaos and the destructing of the enemies of the sun-god Re and Osiris as well ${ }^{(243)}$. Moreover, number seven refers to efficacy in the ancient Egyptian numerological symbolism $^{(244)}$. It is clearly associated to the deciding of the fates. In this context, the seven creative spells ${ }^{(245)}$, which represents the active word of the god which resulted in the creation of the whole world, are involved ${ }^{(246)}$. The seven creative words were frequently attested in the Coffin Texts, such as in Spell 407 ${ }^{(247)}$ and Spells 406 and $408^{(248)}$. Accordingly, number seven is a symbolic number and has a fecund power resulted in the creation process in the ancient Egyptian religion. So that, the reciting of the spells seven times by the queen in the version of the ritual at the Ramesseum and Medinet Habu was highly influenced by the symbolism of number seven, which definitely played a great role in the creative and fertility power of the king and the god in the ritual.

5.8.4. In the version of the ritual in the side room 26 in the great temple of Medinet Habu temple (Fig. 6), the accompanying text alludes to the daily role of god Hapy in giving all the provisions to the king, while he is engaged in mowing the grain to be presented as an eternal and fecund offering in the Iaru-Fields ${ }^{(249)}$. 
Table 1

Summary comparison between the five scenes of the ritual of cutting sheaves of grain in the Theban Temples

\begin{tabular}{|c|c|c|c|c|c|c|c|}
\hline \multirow{2}{*}{$\begin{array}{c}\text { Figure } \\
\text { No. }\end{array}$} & \multirow[t]{2}{*}{ Location } & \multirow[t]{2}{*}{ Deity } & \multirow[t]{2}{*}{ Divine Insignia } & \multirow[t]{2}{*}{ King } & \multicolumn{2}{|c|}{ Royal Regalia } & \multirow{2}{*}{$\begin{array}{c}\text { Sheaves of } \\
\text { Grain }\end{array}$} \\
\hline & & & & & $\begin{array}{l}\text { Crown and } \\
\text { Headdress }\end{array}$ & Garment & \\
\hline (Fig. 2) & $\begin{array}{l}\text { West interior wall, } \\
\text { hypostyle hall, south } \\
\text { half, south part, third } \\
\text { register, Temple of } \\
\text { Amun-Re, Karnak }\end{array}$ & $\begin{array}{l}\text { Amun-Re- } \\
\text { Kamutef }\end{array}$ & $\begin{array}{l}\text { Double feather crown, } \\
\text { long ribbon, curved beard, } \\
\text { mummiform, } \\
\text { flail, and erected penis }\end{array}$ & $\begin{array}{c}\text { Ramesses } \\
\text { II }\end{array}$ & $\begin{array}{l}\text { Headdress } \\
\text { and Uraeus }\end{array}$ & $\begin{array}{l}\text { Light tunic or blouse, a } \\
\text { long pointed skirt, and } \\
\text { ceremonial tail of bull }\end{array}$ & $\begin{array}{l}\text { Ear of emmer } \\
\text { grain plain of } \\
\text { spikes and awns }\end{array}$ \\
\hline (Fig. 3) & $\begin{array}{l}\text { East exterior girdle } \\
\text { wall, Temple of } \\
\text { Amun-Re, Karnak }\end{array}$ & $\begin{array}{l}\text { Amun-Re- } \\
\text { Kamutef }\end{array}$ & $\begin{array}{l}\text { Double feather crown, } \\
\text { long ribbon, curved beard, } \\
\text { mummiform, } \\
\text { flail, and erected penis }\end{array}$ & $\begin{array}{c}\text { Ramesses } \\
\text { II }\end{array}$ & $\begin{array}{l}\text { Blue Crown } \\
\text { and Uraeus }\end{array}$ & $\begin{array}{l}\text { Light tunic or blouse, a } \\
\text { long pointed skirt, and } \\
\text { ceremonial tail of bull }\end{array}$ & $\begin{array}{l}\text { Bundle of grain } \\
\text { stalks with } \\
\text { spikes and awns } \\
\text { laid lengthwise } \\
\text { and tied } \\
\text { together }\end{array}$ \\
\hline (Fig. 4) & $\begin{array}{l}\text { Western side, north } \\
\text { half, inner face, } \\
\text { second pylon, } \\
\text { Ramesseum Temple }\end{array}$ & Min & $\begin{array}{c}\text { sun-disc between two } \\
\text { horns of a bull }\end{array}$ & $\begin{array}{c}\text { Ramesses } \\
\text { II }\end{array}$ & $\begin{array}{l}\text { Blue Crown } \\
\text { and Uraeus }\end{array}$ & $\begin{array}{l}\text { Light tunic or blouse, a } \\
\text { long pointed skirt } \\
\text { decorated with two } \\
\text { cobras, and ceremonial } \\
\text { tail of bull }\end{array}$ & $\begin{array}{l}\text { Ear of emmer } \\
\text { grain plain of } \\
\text { spikes and awns }\end{array}$ \\
\hline (Fig. 5) & $\begin{array}{l}\text { East wall, second } \\
\text { court, Temple of } \\
\text { Medinet Habu }\end{array}$ & Min & $\begin{array}{l}\text { sun-disc between two } \\
\text { horns of a bull }\end{array}$ & $\begin{array}{c}\text { Ramesses } \\
\text { III }\end{array}$ & $\begin{array}{l}\text { hprš- } \\
\text { Blue Crown } \\
\text { and Uraeus }\end{array}$ & $\begin{array}{l}\text { Light tunic or blouse, a } \\
\text { long pointed skirt } \\
\text { decorated with two } \\
\text { cobras, and ceremonial } \\
\text { tail of bull }\end{array}$ & $\begin{array}{l}\text { Bundle of grain } \\
\text { stalks with } \\
\text { spikes and awns } \\
\text { laid lengthwise } \\
\text { and tied } \\
\text { together }\end{array}$ \\
\hline (Fig. 6) & $\begin{array}{c}\text { North wall, Room 26, } \\
\text { Temple of Medinet } \\
\text { Habu }\end{array}$ & Hapy & $\begin{array}{l}\text { Aquatic plant, headdress, } \\
\text { curved beard, short belted } \\
\text { kilt, double } T_{\text {nh-sign, }} \\
\text { and } h_{w 3 s-s c e p t e r}\end{array}$ & $\begin{array}{c}\text { Ramesses } \\
\text { III }\end{array}$ & $\begin{array}{l}\int_{h \underline{d} t-} \\
\text { White } \\
\text { Crown and } \\
\text { Uraeus }\end{array}$ & $\begin{array}{l}\text { Light tunic or blouse, a } \\
\text { long pointed skirt } \\
\text { decorated with two } \\
\text { cobras, and ceremonial } \\
\text { tail of bull }\end{array}$ & $\begin{array}{l}\text { Bundle of grain } \\
\text { stalks with } \\
\text { spikes and awns } \\
\text { laid lengthwise } \\
\text { and tied } \\
\text { together } \\
\end{array}$ \\
\hline
\end{tabular}

213 | P a g e 


\section{Figures}

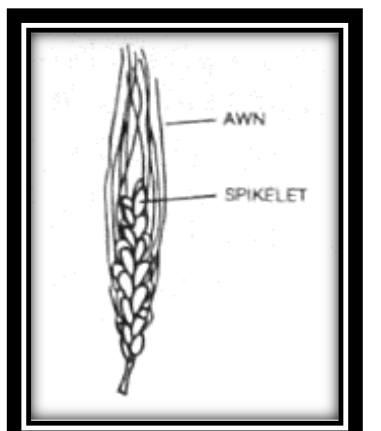

Fig. 1. The triticum dicoccum type of emmer that was used in the ritual of cutting sheaf of grain in the Theban Temples.

After: Murray, M. A., (2000). Cereal Production and Processing, In: P. Nicholson and I. Shaw, eds., Ancient Egyptian Materials and Technology, Cambridge University Press, Cambridge, p. 505, Fig. 21 (1a).

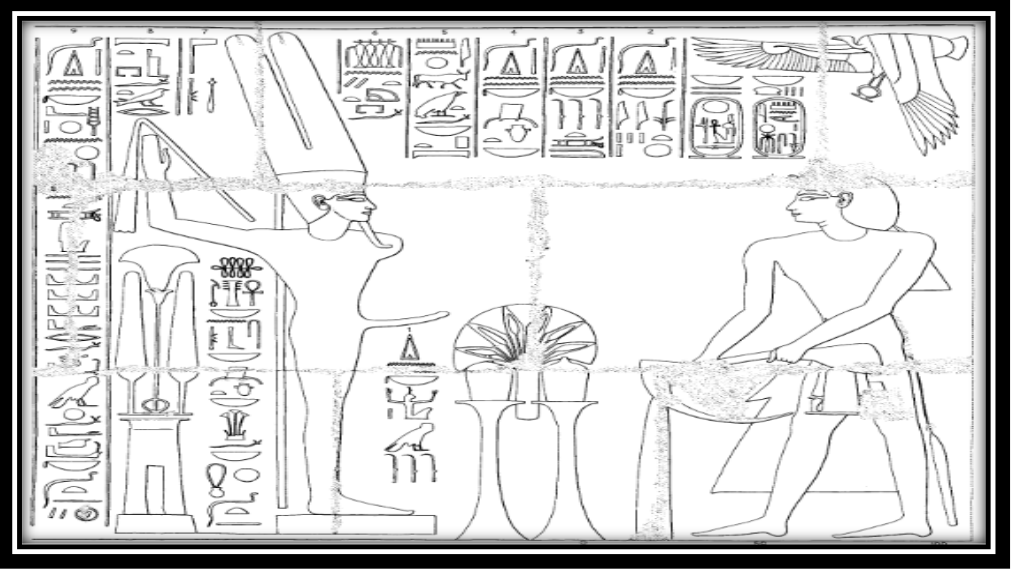

Fig. 2. King Ramesses II cutting sheaf of grain before god Amun-Re-Kamutef on the west interior wall of the hypostyle hall, south half, south part, in the Temple of Amun-Re at Karnak.

After: The Epigraphic Survey, (1940). Medinet Habu, vol. IV, Festival Scenes of Ramses III, The University of Chicago press, Chicago, Illinois, pl. 215 (c).

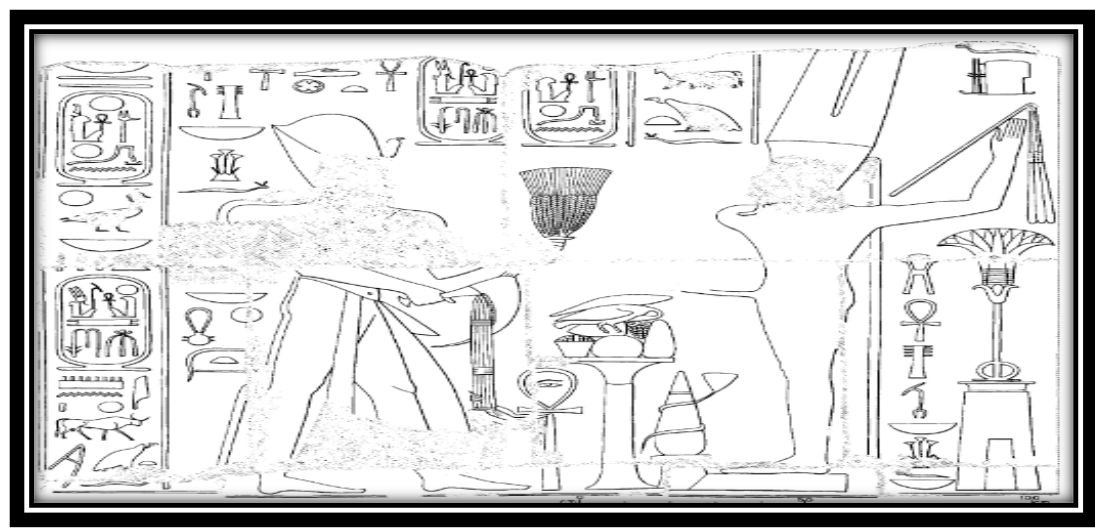

Fig. 3. King Ramesses II cutting sheaf of grain before god Amun-Re-Kamutef on the east exterior girdle wall of the Temple of Amun-Re at Karnak. After: The Epigraphic Survey, (1940), pl. 215 (d). 


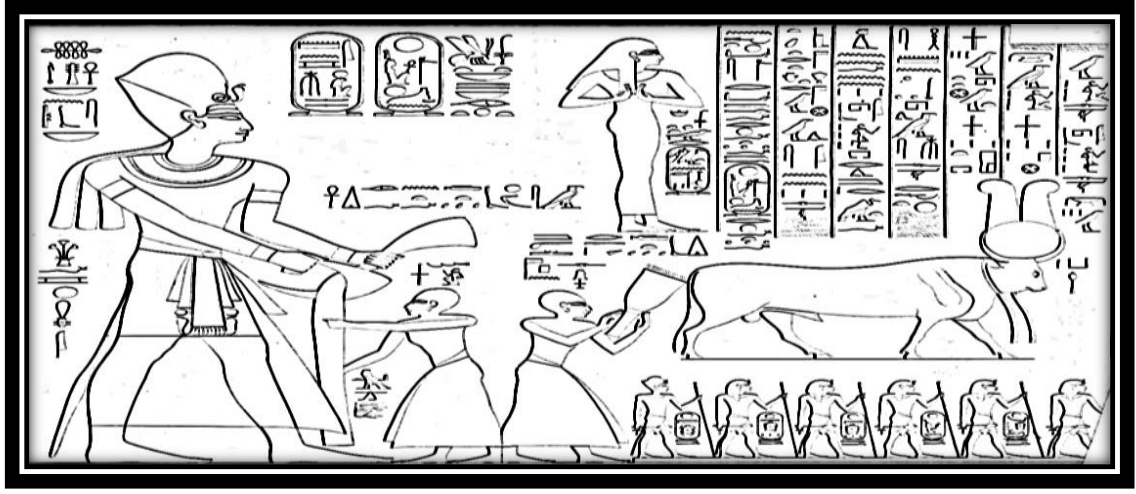

Fig. 4. King Ramesses II cutting sheaf of grain during the ceremonies of the Feast of Min in the upper representation on the western side of the north half on the inner face of the second pylon to the east of the second court in the Ramesseum Temple.

After: Lepsius, K. R., (1972). Denkmaeler aus Aegypten und Aethiopien, vol. III, Éditions de Belles-Lettres, Genève, pl. 162.

Fig. 5. King Ramesses III cutting sheaf of grain during the ceremonies of the Feast of Min on

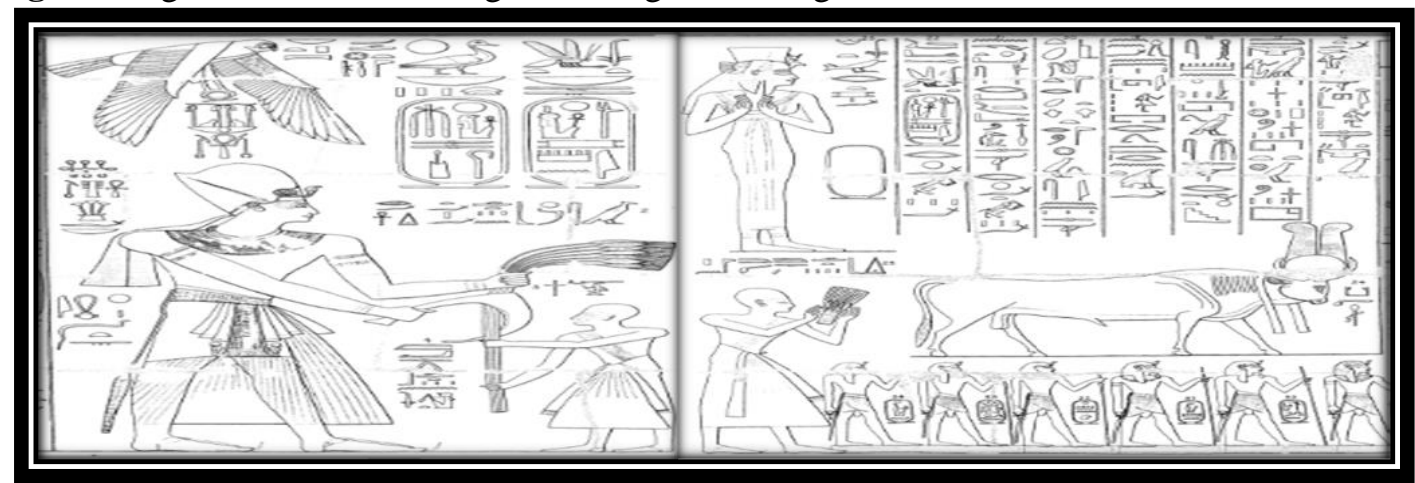

the east wall of the second court in the Great Temple of Medinet Habu After: The Epigraphic Survey, (1940), pls. 205 (b), 207.

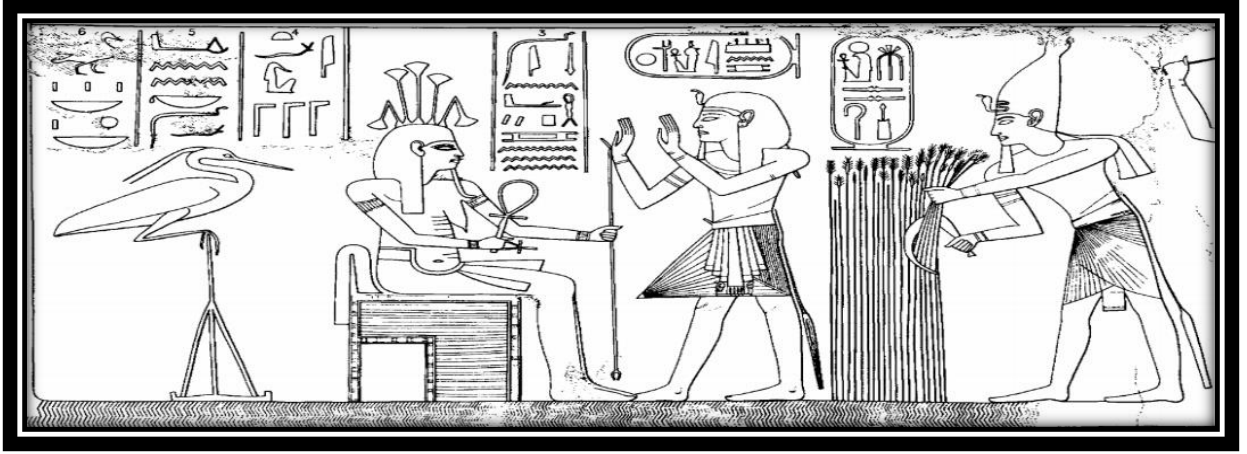

Fig. 6. King Ramesses III cutting grain in the Fields of the Iaru according to Chapter 110 in the Book of the Dead on the north wall of Room 26 in the Great Temple of Medinet Habu After: The Epigraphic Survey, (1963). Medinet Habu, vol. VI, The Temple Proper. Part II.

The Re Chapel, the Royal Mortuary Complex and Adjacent Rooms with Miscellaneous Material from the Pylons, the Forecourts, and the First Hypostyle Hall, The University of Chicago press, Chicago, Illinois, pl. 469. 


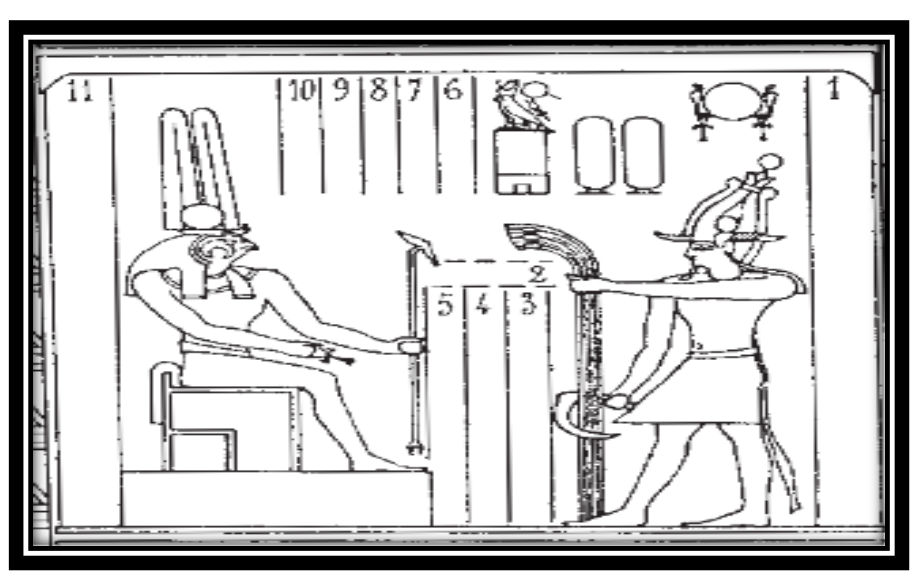

Fig. 7. The King cutting the sheaf of grain before god Horussema-tawy in the northern wall of the central hall in the Temple of god Horus at Edfu. After: Chassinat, É., (1929). Le Temple d'Edfou, Tome IX, (Pl. I-LXXXIII), Institut Français d'Archéologie Orientale, Le Caire, pl. XXXI (a).

\section{Endnotes:}

(1) Lurson, B., (2005). 'La Conception du Décor d'un Temple au Début du Règne de Ramsès II: Analyse du Deuxième Registre de la Moitié sud du Mur Ouest de la Grande Salle Hypostyle de Karnak', The Journal of Egyptian Archaeology 91, Londres, p. 112.

(2) Parker, Richard A., (1950). The Calendars of Ancient Egypt, The Oriental Institute of the University of Chicago, Chicago, p. 39; Schott, S., (1950). Altägyptische Festdaten, Akademie der Wissenschaften und der Literatur, Mainz, Wiesbaden, p. 984; Vandier, J., (1978). Manuel d'archéologie Égyptienne, Tome VI, Bas-Reliefs et Peintures: Scènes de la Vie Agricole à l'Ancien et au Moyen Empire, Éditions A. et J. Picard et Cie, Paris, pp. 80-117; Wilson, P., (1991). A Ptolemaic Lexikon: A Lexicographical Study of the Texts in the Temple of Edfu, Published PhD Thesis, School of Archaeology, University of Liverpool, Leuven, p. 222.

(3) Gauthier, H., (1931). Les Fêtes du Dieu Min, Institut Français d'Archéologie Oriental, Le Caire, p. 247.

(4) Brunner-Traut, E., (1982). 'Minfest', Lexikon der Ägyptologie IV, Harrassowitz Verlag, Wiesbaden, p. 143; Wilson, P., (1991), p. 222; Hannig, L., (2003). Ägyptisches Wörterbuch I, Altes Reich und Erste Zwischenzeit, Ph. von Zabern, Mainz am Rhein, p. 18.

(5) France. Commission des sciences et arts d'Égypte, (1821). Description de l'egypte ou Recueil des Observations et des Recherches qui Ont ete Faites en Egypte Pendant l'expedition, Tome Deuxième, Imprimerie impériale, Paris, pl. 11; Champollion, J., (1844). Monuments de l'Égypte et de la Nubie: Notices Descriptives Conformes aux Manuscrits Autographes Rédigés sur les Lieux, Tome 1, Imprimerie et Librairie de Firmin Didot Frères, Paris, pp. 589-733-734; Rosellini, I., (1844). I Monumenti dell'Egitto e della Nubia. Disegnati dalla Spedizione Scientifico-Letteraria Toscana in Egitto, Distribuiti in Ordine di Materie Interpretati ed Illustrate, Tomo terzo, Monumenti del Culto, Presso Niccolo Capurro, con i caratteri di Didot, Pisa, pl. LXXXVI-LXXVII; Champollion, J.-F., (1845). Monuments de l'Égypte et de la Nubie, d'après les Dessins Exécutés sur les Lieux, Tome Deuxième, Imprimerie et Librairie de Firmin Didot Frères, Paris, pls. CL, CCXIV; Wilkinson, J. G., (1878). Manners and Customs of the Ancient Egyptians, A New Edition, Revised and Corrected by Samuel Birch, Vol. III, John Murray, London, pl. LX; Gauthier, H., (1931), pl. VI (right); The Epigraphic Survey, (1940). Medinet Habu, vol. IV, Festival Scenes of Ramses III, The University of Chicago press, Chicago, Illinois, pls. 196 (b), 205 (b), 206 (b), 214 (a); Lepsius, K. R., (1972). Denkmaeler aus Aegypten und Aethiopien, vol. III, Éditions de Belles-Lettres, Genève, pls. 162, 212 (b).

(6) Chassinat, É., (1929). Le Temple d'Edfou, Tome IX, (Pl. I-LXXXIII), Institut Français d'Archéologie Orientale, Le Caire, pl. XXXI (a); De Rochemonteix, M. and Chassinat, E., (1931). Le Temple d'Edfou, Tome VI, Institut Français d'Archéologie Orientale, Le Caire, p. 
280:1 (Tableau I'e. 2 g. VII); De Rochemonteix, M. and Chassinat, E., (1984). Le Temple d'Edfou, Tome I, Institut Français d'Archéologie Orientale, Le Caire, p. 384:2 (Tableau Nn. 3g.).

(7) De Rochemonteix, M. and Chassinat, E., (1984), p. 280 (Tableau I'e. 2 g. VIII).

(8) Faulkner, R. O., (1962). A Concise Dictionary of Middle Egyptian, Griffith Institute, Oxford, p. 6; Erman, A. and Grapow, H., (1971). Wörterbuch der Ägyptischen Sprache, Band I, Akademie Verlag, Berlin, p. 19: 15-16; Wilson, P., (1991), pp. 42-43; Van der Molen, R., (2000). A Hieroglyphic Dictionary of Egyptian Coffin Texts, Brill, Leiden, Boston, Köln, p. 8; Hannig, L., (2003), p. 18; Hannig, R., (2006). Ägyptisches Wörterbuch II, Mittleres Reich und Zweite Zwischenzeit, Verlag Philipp von Zabern, Mainz am Rhein, p. 43.

(9) Faulkner, R. O., (1962), p. 6; Erman, A. and Grapow, H., (1971), Band I, p. 19: 15-16. The sign (3) is substituted by the sign $4_{(i)}$ particualry that the sign ${ }_{(i)}$ at the beginning of words was sometimes identical with the sign (3) in the ancient Egyptian language. Gardiner, A. H., (1927). Egyptian Grammar: Being an Introduction to the Study of Hieroglyphs, Clarendon press, Oxford, p. 27.

(10) Faulkner, R. O., (1962), p. 32; Erman, A. and Grapow, H., (1971), Band I, p. 142: 10-20; Wilson, P., (1991), pp. 221-222; Van der Molen, R., (2000), p. 57; Lesko, L. H., (2002). A Dictionary of Late Egyptian, vol. I, $2^{\text {nd }}$ Edition, B. C. Scribe Publications, Berkeley, California, p. 50; Hannig, L., (2003), pp. 233-235; Hannig, R., (2006), pp. 436-438.

(11) Faulkner, R. O., (1962), p. 86; Erman, A. and Grapow, H., (1971), Band I, pp. 486: 14487:7; Wilson, P., (1991), p. 619; Van der Molen, R., (2000), pp. 125-126; Hannig, L., (2003), pp. 428-429; Hannig, R., (2006), pp. 828-829.

(12) Faulkner, R. O., (1962), p. 85; Erman, A. and Grapow, H., (1971), Band I, pp. 486: 14; Van der Molen, R., (2000), p. 125; Lesko, L. H., (2002), p. 143; Hannig, L., (2003), p. 828.

(13) Erman, A. and Grapow, H., (1971), Band I, pp. 486: 15-16.

(14) Mariette, A., (1889). Les de l'Ancien Empire, F. Vieweg, Paris, pp. 212 (D15), 246; Steindorff, G., (1913). Das Grab des Ti, J. C. Hinrichs'sche Buchhandlung, Leipzig, Tf. 121; Wild, H., (1966). Le Tombeau de Ti, Fascicule III, La Chapelle, 2ème partie, Impr. de l'Institut français d'archéologie orientale, Le Caire, pl. CXLIX; Porter, B. and Moss, R. L. B., (1978). Topographical Bibliography of Ancient Egyptian Hieroglyphic Texts, Reliefs and Paintings, vol. III $^{2}$, Memphis, Griffith Institute, Ashmolean Museum, Oxford, pp. 472 (34), 481 (2).

(15) Kanawati, N., (2012). The Cemetery of Meir I: The Tomb of Pepyankh the Middle, Aris \& Phillips, Oxford, p. 49, pls. 37, 44a, 84.

(16) Davies, N. G., (1901). The Rock Tombs of Sheikh Saïd, Egypt Exploration Fund, London, p. 22, pl. XVI; Porter, B. and Moss, R. L. B., (1934). Topographical Bibliography of Ancient Egyptian Hieroglyphic Texts, Reliefs and Paintings, vol. IV, Lower and Middle Egypt (Delta and Cairo to Asyut), Griffith Institute, Ashmolean Museum, Oxford, p. 188 (6).

(17) Junker, H., (1943). Gîza. VI. Bericht über die von der Akademie der Wissenschaften in Wien auf gemeinsame Kosten mit Dr. Wilhelm Pelizaeus unternommenen Grabungen auf dem Friedhof des Alten Reiches bei den Pyramiden von Gîza, Band VI, Die Mastabas des Nfr (Nefer), Kdfjj (Kedfi), K3hjf (Kahjef) und die westlich anschliessenden Grabanlagen / herausgegeben von Hermann Junker, Hölder-Pichler-Tempsky, Wien, Leipzig, pp. 59, 69, Abb. 14, 17; Porter, B. and Moss, R. L. B., (1978), p. 138.

(18) Mercer, S. A. B., (1952). The Pyramid Texts: In Translation and Commentary, vol. I, Translation of the Texts, Longmans, green and co., New York, London, Toronto, p. 469; Faulkner, R. O., (1969). The Ancient Egyptian Pyramid Texts, vol I, English Translation, 
Clarendon Press, Oxford, p. 280 (\$1936); Faulkner, R. O., (1969). The Ancient Egyptian Pyramid Texts, vol II, Supplement of Hieroglyphic Texts, Clarendon Press, Oxford, p. 39 (\$1936d).

(19) Quibell, J. E., (1907). Excavations at Saqqara (1905-1906), Imprimerie de l'nstitut Français d'Archéologie Orientale, Le Caire, p. 26, pl. 20 (2); Porter, B. and Moss, R. L. B., (1978), p. 564.

(20) De Buck, A., (1951). The Egyptian Coffin Texts, vol. IV, Texts of Spells, 268-354, The University of Chicago Press, Chicago, p. 169 (g); Faulkner, R. O., (1973). The Ancient Egyptian Coffin Texts, vol. 1, Spells 1-354, Aris \& Philips, Warminster, p. 2,55.

(21) De Buck, A., (1935). The Egyptian Coffin Texts, vol. I, Texts of Spells, 1-75, The University of Chicago Press, Chicago, p. 286 (a); Faulkner, R. O., (1973), p. 63.

(22) De Buck, A., (1935), p. 300 (g); Faulkner, R. O., (1973), p. 67.

(23) De Buck, A., (1956). The Egyptian Coffin Texts, vol. VI, Texts of spells 472-786, The University of Chicago Press, Chicago, p. 173 (g); Faulkner, R. O., (1977). The Ancient Egyptian Coffin Texts, vol. 2. Spells 355-787, Aris \& Philips, Warminster, p. 173.

(24) De Buck, A., (1956), p. 355 (g); Faulkner, R. O., (1977), p. 276.

(25) De Buck, A., (1954). The Egyptian Coffin Texts, vol. V, Texts of Spells, 355-471, The University of Chicago Press, Chicago, p. 99 (d); Faulkner, R. O., (1977), p. 26.

(26) De Buck, A., (1954), p. 153 (b); Faulkner, R. O., (1977), p. 36.

(27) De Buck, A., (1947). The Egyptian Coffin Texts, vol. III, Texts of Spells, 164-267, The University of Chicago Press, Chicago, p. 134 (d-e); Faulkner, R. O., (1973), p. 164.

(28) De Buck, A., (1947), pp. 236 (b), 237 (a); Faulkner, R. O., (1973), p. 177.

(29) De Buck, A., (1956), p. 14 (d-e); Faulkner, R. O., (1977), p. 109.

(30) De Buck, A., (1938). The Egyptian Coffin Texts, vol. II, Texts of Spells, 76-163, The University of Chicago Press, Chicago, p. 370 (b); Faulkner, R. O., (1973), p. 138.

(31) De Buck, A., (1954), p. 199 (g); Faulkner, R. O., (1977), p. 50.

(32) De Buck, A., (1954), p. 356 (XIV); Faulkner, R. O., (1977), p. 93.

(33) De Buck, A., (1954), p. 378 (c); Faulkner, R. O., (1977), p. 96.

(34) De Buck, A., (1947), p. 287 (b); Faulkner, R. O., (1973), p. 181.

(35) Weeks, K. R., (1994). Mastabas of Cemetery G 6000: Including G 6010 (Neferbauptah); G 6020 (Iymery); G 6030 (Ity); G 6040 (Shepseskafankh), Museum of Fine Arts, Boston, p. 47, fig. 40, pl. 24 (a).

(36) Weeks, K. R., (1994), p. 47, fig. 40, pl. 24 (a).

(37) Steindorff, G., (1913), Tf. 121.

(38) Sethe, K., (1908). Altaegyptischen Pyramidentexte: Nach den Papierabdrücken und Photographien des Berliner Museums, Erster Band, Text, Erste Hälfte, Spruch I-468 (Pyr. I905), J. C. Hinrichs, Leipzig, p. 361; Mercer, S. A. B., (1952), p. 203; Faulkner, R. O., (1969), vol I, p. $124(\$ 657 \mathrm{a})$.

(39) Sethe, K., (1910). Altaegyptischen Pyramidentexte: Nach den Papierabdrücken und Photographien des Berliner Museums, Zweite Hälfte, Spruch 469-714 (Pyr. 906-2217), J. C. Hinrichs, Leipzig, p. 420; Mercer, S. A. B., (1952), p. 433; Faulkner, R. O., (1969), vol I, p. $257(\S 1748)$.

(40) Mercer, S. A. B., (1952), p. 510; Faulkner, R. O., (1969), vol I, p. 302 (§2128); Faulkner, R. O., (1969), vol. II, p. 54 (\$2128c).

(41) Sethe, K., (1908), p. 488; Mercer, S. A. B., (1952), p. 252; Faulkner, R. O., (1969), vol I, p. 154 (\$874). Compare with fig. (Fig. 7) the ritual of cutting grain in the Fields of the Iaru by King Ramesses III according to Chapter 110 in the Book of the Dead on the north wall of Room 26 in the great temple of Medinet Habu. The Epigraphic Survey, (1963). Medinet Habu, 
vol. VI, The Temple Proper, Part II, The Re Chapel, the Royal Mortuary Complex and Adjacent Rooms with Miscellaneous Material from the Pylons, the Forecourts, and the First Hypostyle Hall, The University of Chicago press, Chicago, Illinois, pl. 469.

(42) Sethe, K., (1910), p. 470; Mercer, S. A. B., (1952), p. 474; Faulkner, R. O., (1969), vol. I, p. $282(\$ 1950)$.

(43) Lepsius, K. R., (1972), pls. 163-164 (a).

(44) The Epigraphic Survey, (1940), pl. 205 (b).

(45) Bleeker, C. J., (1956). Die Geburt Eines Gottes: Eine Studie über den Ägyptischen Gott Min und sein Fest, Brill, Leiden, p. 82 (no. 18).

(46) Gauthier, H., (1931), pp. 37-38; Maher-Taha, M. and Loyrette, A.-M., (1979). Le Ramesseum, vol. XI, Les Fêtes du Dieu Min, Collection Scientifique du CEDAE, CS 36, Le Caire, pls. 4 (b)-6, 17-19.

(47) Murray, M. A., (2000). Cereal Production and Processing, In: P. Nicholson and I. Shaw, eds., Ancient Egyptian Materials and Technology, Cambridge University Press, Cambridge, New York, Melbourne, p. 520.

(48) Seele, K. C., (1940). The Coregency of Ramses II with Seti I and the Date of the Great Hypostyle Hall at Karnak, The University of Chicago Press, Chicago, p. 17, fig. 7; The Epigraphic Survey, (1940), pl. 215 (c); Barguet, P., (1962). Le Temple d'Amon-Rê à Karnak, Institut Français d'Archéologie Orientale, Le Caire, p. 65 (g); Porter, B. and Moss, R. L. B., (1972). Topographical Bibliography of Ancient Egyptian Hieroglyphic Texts, Reliefs and Paintings, vol. II, Theban Temples, Griffith Institute, Ashmolean Museum, Oxford, p. 46; Nyslon, H. H. and Murnane, W., J. eds., (1981). The Great Hypostyle Hall at Karnak, vol. 1, Part 1, The Wall Reliefs, The Oriental Institute of the University of Chicago, Chicago, Illinois, pl. 28; El-Sharkawy, A., (1997). Der Amun-Tempel von Karnak. Die Funktion der Großen Säulenhalle, Erschlossen aus der Analyse der Dekoration ihrer Innenwände, Verlag Dr. Köster, Berlin, p. 36; Lurson, B., (2005), pp. 112-113; Brand, P. J., Feleg, R. E. and Murnane, W. J., (2018). The Great Hypostyle Hall: In the Temple of Amun at Karnak, vol. 1, Part 2, The Oriental Institute of the University of Chicago, Chicago, p. 69; Brand, P., Feleg, R. E and Murnane, W. J., (2018). The Great Hypostyle Hall in the Temple of Amun at Karnak, vol. 1, part 3, Figures and Plates, The Oriental Institute of the University of Chicago, Chicago, fig. 261, 304, 354, pl. 28.

(49) France. Commission des sciences et arts d'Égypte, (1821). Description de l'Égypte ou Recueil des Observations et des Recherches qui Ont été Faites en Égypte Pendant L'Expédition de L'Armée Française, Tome Troisième, Imprimerie impériale, Paris, pl. 36 (4); The Epigraphic Survey, (1940), pl. 215 (d); Barguet, P., (1962), p. 214 (3); Helck, W., (1968). Die Ritualszenen auf der Umfassungsmauer Ramses'II. in Karnak, Harrassowitz, Wiesbaden, p. 82, pl. 44, fig. 65; Porter, B. and Moss, R. L. B., (1972), p. 129;.

(50) Brand, P. J., Feleg, R. E. and Murnane, W. J., (2018), vol. 1, Part 2, p. 69.

(51) Wilfong, T. G., (2013), p. 39.

(52) Christiane, Z.-C., (2004). Gods and men in Egypt: 3000 BCE to 395 CE, Ithaca, NY: Cornell Univ. Press, p. 18.

(53) Hart, G., (1986). A Dictionary of Egyptian Gods and Goddesses, Routledge \& Kegan Paul, London, Boston, Henley, pp. 15-16.

(54) Helck, W., (1968), p. 82.

(55) Gauthier, H., (1931), p. 166; Griffiths, J. G., (1960), The Conflict of Horus and Seth from Egyptian and Classical Sources: A Study in Ancient Mythology, Liverpool University press, Liverpool, p. 46; Kees, H., (1956). Der Götterglaube im Alten Aegypten, Akademie-Verlag, Leipzig, p. 91; Helck, W., (1968), p. 82. 
(56) Brand, P. J., Feleg, R. E. and Murnane, W. J., (2018), vol. 1, Part 2, p. 69.

(57) The Epigraphic Survey, (1940), pl. 215 (c).

(58) Brand, P. J., Feleg, R. E. and Murnane, W. J., (2018), vol. 1, Part 2, p. 69.

(59) The Epigraphic Survey, (1940), pl. 215 (c).

(60) Brand, P. J., Feleg, R. E. and Murnane, W. J., (2018), vol. 1, Part 2, p. 69.

(61) The Epigraphic Survey, (1940), pl. 215 (c).

(62) Brand, P. J., Feleg, R. E. and Murnane, W. J., (2018), vol. 1, Part 2, p. 69.

(63) The Epigraphic Survey, (1940), pl. 215 (c).

(64) Brand, P. J., Feleg, R. E. and Murnane, W. J., (2018), vol. 1, Part 2, p. 69.

(65) The Epigraphic Survey, (1940), pl. 215 (c).

(66) Brand, P. J., Feleg, R. E. and Murnane, W. J., (2018), vol. 1, Part 2, p. 69.

(67) The Epigraphic Survey, (1940), pl. 215 (c).

(68) Brand, P. J., Feleg, R. E. and Murnane, W. J., (2018), vol. 1, Part 2, p. 69.

(69) Helck, W., (1968), p. 82.

(70) Brand, P. J., Feleg, R. E. and Murnane, W. J., (2018), vol. 1, Part 2, p. 69.

(71) Helck, W., (1968), p. 82.

(72) The Epigraphic Survey, (1940), pl. 215 (d).

(73) Champollion, J., (1844), p. 589; Rosellini, I., (1844), pl. LXXVII; Champollion, J.-F., (1845), pl. CL; The Epigraphic Survey, (1940), pl. 214 (a); Lepsius, K. R., (1972), pl. 162; Porter, B. and Moss, R. L. B., (1972), p. 434.

(74) France. Commission des sciences et arts d'Égypte, (1821), Tome Deuxième, pl. 11; Champollion, J., (1844), pp. 733-734; Rosellini, I., (1844), pl. LXXXVI; Champollion, J.-F., (1845), pl. CCXIV; Wilkinson, J. G., (1878), pl. LX; Gauthier, H., (1931), pl. VI (righ); The Epigraphic Survey, (1940), pls. 196 (b), 205 (b), 206 (b); Lepsius, K. R., (1972), pl. 212 (b); Porter, B. and Moss, R. L. B., (1972), p. 500.

(75) Gauthier, H., (1931), p. 226.

(76) Daressy, G., (1897). Notice Explicative des Ruines de Médinet Habou, Service des antiquités de l'Égypte, Le Caire, p. 125; Gauthier, H., (1931), p. 227; Bleeker, C. J., (1956), p. 82.

(77) Gauthier, H., (1931), p. 226; Bleeker, C. J., (1956), p. 82.

(78) Gauthier, H., (1931), p. 226.

(79) Gauthier, H., (1931), p. 227.

(80) Gauthier, H., (1931), p. 227.

(81) Gauthier, H., (1931), pp. 61-62; Lepsius, K. R., (1972), pls. 163-164 (a); Kitchen, K. A., (1983). Ramesside inscriptions: Historical and Biographical, vol. V, Blackwell, Oxford, p. 201: 11-15.

(82) Daressy, G., (1897), p. 124; Gauthier, H., (1931), p. 63 (5); Jacobsohn, H., (1939). Die Dogmatische Stellung des Königs in der Theologie der Alten Ägypter, Augustin Glückstadt, Glückstadt, p. 34.

(83) Lepsius, K. R., (1972), pls. 163-164 (a); Kitchen, K. A., (1983), vol. V, p. 211: 4.

(84) Bleeker, C. J., (1956), p. 82 (no. 18).

(85) Kitchen, K. A., (1983), vol. V, p. 210: 14-15. in Lepsius, K. R., (1972), pl. 162, this text

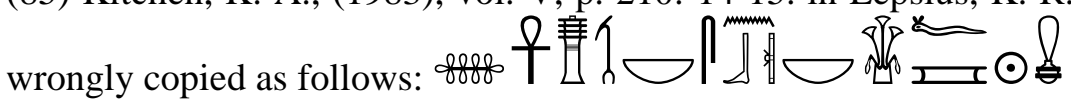

(86) Gauthier, H., (1931), pp. 61-62; Jacobsohn, H., (1939), p. 34; Kitchen, K. A., (1983), vol. V, p. 201: 11-15. 
(87) For the translation of the Faulkner, R. O., (1962), p. 19.

(88) Daressy, G., (1897), p. 124; Gauthier, H., (1931), pp. 63 (5), 227-228; Jacobsohn, H., (1939), p. 34.

(89) Kitchen, K. A., (1983), vol. V, p. 211: 5; The Epigraphic Survey, (1940), pl. 205 (b).

(90) Bleeker, C. J., (1956), p. 82 (no. 18).

(91) The Epigraphic Survey, (1940), pl. 205 (b); Kitchen, K. A., (1983), vol. V, p. 210: 15.

(92) Moret, A., (1927). Mystères Égyptiens, Librairie Armand Colin, Paris, fig. 39; Hölscher, U., (1941). The Excavation of Medinet Habu, Volume III, The Mortuary Temple of Ramses III, Part I, translated by Keith Cedric Seele, The University of Chicago press, Chicago, Illinois, p. 17; Noblecourt, Ch., (1950). 'À Propos de l'obélisque de Saint-The Jouranl of Egyptian Archaeologyn-de-Latran et d'un Sanctuaire en Vogue à Karnak à la Fin de la XVIIIe Dynastie. Nouveaux Exemples de Scarabées Commémoratifs de la XVIIIe Dynastie', Annales du Service des antiquités de l'Égypte 50, Le Caire, , fig. 9, p. 266; Desroches- The Epigraphic Survey, (1963), pl. 469; Porter, B. and Moss, R. L. B., (1972), p. 511; Lurson, B., (2005), p. 112 (no. 20).

(93) Gesellensetter, J. S., (1997), pp. 12, 17.

(94) The luster and the good growth of the ears of grain in the field point to the representation of their unusual size. They are as high as the king. It seems clear that the exaggeration in the size of the corpses in the eternal fields sheds the light on the concept of the including of bigger and better corpses in the otherworld than those in the terrestrial world. Wilkinson, R. H., (1994), p. 52.

(95) Hart, G., (1986), p. 76.

(96) Hart, G., (1986), p. 75.

(97) The Epigraphic Survey, (1963), pl. 469.

(98) Germer, R., (1986), 'Weizen', Lexikon der Ägyptologie VI, Harrassowitz Verlag, Wiesbaden, p. 1210; Samuel, D., (2009). Experimental Grinding and Ancient Egyptian Flour Production, In: S. Ikram and A. Dodson, eds., Beyond the Horizon: Studies in Egyptian Art, Archaeology and History in Honour of Barry J. Kemp, The Supreme council of Antiquities, Cairo, p. 456.

(99) Murray, M. A., (2000), p. 512.

(100) Kees, H., (1961). Ancient Egypt: A Cultural Topography, Faber and Faber, London, p. 74; Helck, W., (1977). 'Getreide', Lexikon der Ägyptologie II, Harrassowitz Verlag, Wiesbaden, pp. 586; Germer, R., (1985). Flora des Pharaonischen Ägypten, Philipp von Zabern, Mainz am Rhein, p. 211; Germer, R., (1986), p. 1209; Murray, M. A., (2000), p. 505, Fig. 21 (1a); Hannig, L., (2003), p. 428.

(101) Saffirio, L., (1973). Food and Dietary Habits in Ancient Egypt, In: D. R. Brothwell, B. Chiarelli, eds., Population Biology of the Ancient Egyptians, vol. 1, Academic Press, London, pp. 299-300.

(102) Germer, R., (1986), p. 1209.

(103) Kees, H., (1961), p. 74; Lloyd, A., (1983). The Late Period, 664-323 BC, In: B. G. Trigger, B. J. Kemp, D. O'Connor, and A. B. Lloyd, eds., Ancient Egypt: A Social History, Cambridge University Press, Cambridge, London, p. 327; Germer, R., (1986), p. 1209; Murray, M. A., (2000), p. 512.

(104) Gardiner, A., (1941). 'Ramesside Texts Relating to the Taxation and Transport of Corn', The Journal of Egyptian Archaeology 27, Londres, p. 23; Janssen, J., (1975). Commodity Prices 
from the Ramesside Period: An Economic Study of the Village Necropolis Workmen at Thebes, Brill, Leiden, p. 460; Murray, M. A., (2000), p. 512.

(105) Murray, M. A., (2000), p. 512.

(106) Kamil. J., (1984). The Ancient Egyptians Life in the Old Kingdom, The American University in Cairo press, Cairo, p. 129; Whale, S., (1989). The Family in the Eighteenth Dynasty of Egypt - A Study of the Representation of the Family in Private Tombs, Australian Centre for Egyptology, Sydney, p. 52; Watterson, B., (1991). Women in Ancient Egypt, Alan Sutton, Stroud, St. Martin's Press, New York, p. 26; Robins, G., (1993). Women in Ancient Egypt, British Museum Press, London, pp. 99, 107.

(107) Campbell, C., (1912). Miraculous Birth of King Amenhotep III and Other Egyptian Studies, Oliver and Boyd, Edinburgh, pp. 159-167, pl. on p. 160; Bruyère, B., (1959). La Tombe $N^{O} 1$ de Sen-Nedjem à Deir el-Médineh, Institut Français d'Archéologie Orientale, Le Caire, pp. 36-37, pl. XXVII; Toda, E., (1887). Son Notém en Tebas: Sennedyem en Tebas, Editorial Ausa, Sabadell, pl. opposite p. 45;Wreszinski, W., (1923). Atlas zur altägyptischen Kulturgeschichte, vol. I, Hinrichs'sche Buchhandlung, Leipzig, pls. 14, pl. 19 (a); Weigall, A. E. P., (1924).Ancient Egyptian Work of Art, T.F. Unwin, London, p. 258; Capart, J. and Werbrouk, M., (1925). Thèbes: La Glorie d'un Grand Passé, chez Vromant \& Cie, coll, Bruxelles, p. 339, fig. 250; Jourdain, G., (1939). Deux Tombes de Deir El-Médineh, La Tombe du Scribe Royal Amenemopet, Institut Français d'Archéologie Orientale, Le Caire, pp. 30-31, pls. XIX, XXI; Porter, B. and Moss, R. L. B., (1972), pp. 53-54, 155; Hodel-Hoenes, S., (2000). Life and Death in Ancient Egypt - Scenes from Private Tombs in New Kingdom Thebes, Cornell University Press, Ithaca, New York, London, pp. 253 - 255, figs. 181-183.

(108) Hornung, E., (1979). Das Totenbuch der Ägypter, Artemis Verlag, Zürich, München, p. 217; Saleh, M., (1984). Das Totenbuch in den Thebanischen Beamtengräbern des Neuen Reiches, Philipp von Zabern, Mainz am Rhein, pp. 58-61; Faulkner, R., (1985). The Ancient Egyptian Book of the Dead, British Museum publications, London, pp. 103-108, 110-111; Hodel-Hoenes, S., (2000), pp. 254.

(109) Gauthier, H., (1931), p. 252.

(110) Mercer, S. A. B., (1952), p. 469; Faulkner, R. O., (1969), vol I, p. 280 (§1936).

(111) Gauthier, H., (1931), p. 229.

(112) Sethe, K., (1908), p. 488; Mercer, S. A. B., (1952), p. 252; Faulkner, R. O., (1969), vol I, p. 154 (\$874).

(113) Gardiner, A. H., (1937). Late-Egyptian Miscellanies, Fondation Égyptologique Reine Élisabeth, Bruxelles, p. 45: 15; Barguet, P., (1962), pl. VII B; Nyslon, H. H. and Murnane, W., J., eds., (1981). The Great Hypostyle Hall at Karnak, vol. 1, Part 1, The Wall Reliefs, The Oriental Institute of the University of Chicago, Chicago, Illinois, pl. 36 (3-4); Schwaller de Lubicz, R. A., (1982). Les Temples de Karnak: Contribution à l'étude de la Pensée Pharaonique, Dervy-Livres, Paris, pl. 88; Albouy, M., Boccon-Gibod, H., J.-C., Golvin and Goyon, J.-C., Martinez, Ph., (1989). Karnak: Le Temple d'Amon Restitué par l'ordinateur, M.A Editions, Paris, pp. 150-151; Brand, P. J., Feleg, R. E. and Murnane, W. J., (2018), vol. 1, Part 2, p. 78. For further discussion about god Amun as the source of the Nile flood, see: Gabolde, M., (1995). L'inondation sous les pieds d'Amon, Bulletin de l'Institut Français d'Archéologie Orientale 95, Le Le Caire, pp. 235-258, figs. 1-2.

(114) Monnet, J., (1955). Un Monument de la Corégence des Divines Adoratrices Nitocris et Ankhnesneferibré, Revue d' Égyptologie, la Société Française d' Égyptologie 10, Paris, , p. 44. (115) Wilkinson, R. H., (2003). The Complete Gods and Goddesses of Ancient Egypt, The American University in Cairo Press, Cairo, p. 115. 
(116) Bardoňová, M., (2019). Grain Storage in Ancient Egypt (2600-1650 BC): Typology and Socio-Economic Implications, Unpublished PhD Thesis, Faculty of Arts, Czech Institute of Egyptology, Charles University, p. 260.

(117) Assmann, J., (2001). Tod und Jenseits im Alten Ägypten, C.H.Beck, München, p. 231.

(118) Assmann, J., (2007). Creation Through Hieroglyphs: The Cosmic Grammatology of Ancient Egypt, In: S. La Porta, D. Shulman, eds., The Poetics of Grammar and the Metaphysics of Sound and Sign, Brill, Leiden, Boston, p. 19.

(119) Bonnet, H., (1952). Reallexikon der Ägyptischen Religionsgeschichte, Walter de Gruyter, Berlin, p. 392.

(120) Raven, M. J., (1997). Four Corn-mummies in the Archaeological Museum at Cracow, Materialy Archeologiczne XXX, Krakowie, p. 16.

(121) Centrone, M. C., (2006). Corn-Mummies, Amulets of Life, In: K. Szpakowska, ed., Through a Glass Darkly: Magic, Dreams \& Prophecy in Ancient Egypt, The Classical Press of Wales, Swansea, p. 33.

(122) Wilkinson, J. G., (1835). Topography of Thebes and General View of Egypt, John Murray, London, 79; Raven, M. J., (1997). Four Corn-mummies in the Archaeological Museum at Cracow, Materialy Archeologiczne XXX, Krakowie, p. 6; Goyon, G. J., (2008). Deux Pionniers Lyonnais de la Paléo-Écologie de la Vallée du Nil Égyptien: Victor Loret (18591946) et Louis Lortet (1836-1909), In: C. Michel, ed., La Passion de la Collecte, du Muséum au Musée des Confluences, Musée des Confluences, Lyon, p. 170.

(123) Raven, M. J., (1997), p. 18.

(124) Wilfong, T. G., (2013). Life, Death, and Afterlife in Ancient Egypt: The Djehutymose Coffin in the Kelsey Museum of Archaeology, Kelsey Museum of Archaeology, Michigan, p. 33.

(125) Bonnet, H., (1952), p. 392; Raven, M. J., (1963). Corn-mummies, Oudheidkundige mededelingen van het Rijksmuseum van Oudheden te Leiden 63, Leiden, p. 7, 9, 20.

(126) Moret, A., (1902). Le Rituel du Culte Divin Journalier en Égypte: d'après les Papyrus de Berlin et les Textes du Temple de Séti Ier, à Abydos, Ernest Leroux, Paris, p. 69; Naville, E., (1906). The Temple of Deir El Bahari, Part V, The Upper Court and Sanctuary, Plates CXIXCL, Egypt Exploration Fund, London, pls. CXXXI-CXXXII; Sethe, K. H., (1909). Urkunden der 18. Dynastie, vol. IV., Historisch-Biographische Urkunden, J. C. Hinrichs'sche Buchhandlung, Leipzig, p. 93: 13; Gauthier, H., (1912). Le Temple de Ouadi es-Sebouâ, vol. I, Texte, vol. II, Planches, Service des Antiquités de l'Égypte, Le Caire, p. 227, 234, pl. 64; Calverley, A. M. and Gardiner, A. H., (1935). The Temple of King Sethos I at Abydos, vol. II, The Chapels of Amen-Rē,' Rēe'Harakhti, Ptah, and King Sethos, The Egypt Exploration Society, London, pls. 4-5; Calverley , A. M., (1935). The Temple of King Sethos I at Abydos, vol. IV, The Second Hypostyle Hall, The Egypt Exploration Society, London; The Oriental Institute of the University of Chicago, Chicago, pls. 21, 54, 72; Edwards I. E. S. ed., (1939). Hieroglyphic Texts from Egyptian Stelae, \&C., in the British Museum, part 8, The Trustees of the British Museum, London, p. 30, pl. XXVI; Chevrier, H., (1940). Le Temple Reposoir de Séti II à Karnak, Imprimerie Nationale, Le Caire, p. 15; Fakhry, A., (1942). Bahria Oasis, vol.1, Service des antiquités de 1'Egypte, Le Caire, p. 66, pl. 26, fig. 23 (B); Christophe, L.-A., (1955). Temple d'Amon à Karnak: Les Divinités des Colonnes de la Grande Salle Hypostyle et Leurs Épithètes, Impr. de l'Institut Français d'Archéologie Orientale, Le Caire, pp. 34, 40, 51, 83; Goyon, J.-C., (1973). Le Ramesseum, vol. I, Centre d'Etude et de Documentation sur l'Ancienne Egypte, Le Caire, pp. 55, 61, pls. XXVI, XXXVI; Doresse, M., (1973). 'Le Dieu Voilé dans sa Châsse et la Fête du Début de la Décade [II]', Revue d' Égyptologie, la Société Française d' Égyptologie 25, Paris, p. 102, fig. 1; El-Tanbouli, M. A. L., Kuentz, C. and Sadek A. A., (1975). Gerf Hussein III, La Grand Salle (E) Mur Est - Piliers et Colosses, Centre de Documentation et d'Études sur l'Ancienne Égypte, Le Caire, p. 67, pl. XXXIII; Brunner-Traut, E., (1977). Die Friedlichen Räume des Tempels von Luxor, Von Zabern, Mainz am Rhein, p. 
75; p. 227; The Epigraphic Survey, (1979). The Temple of Khonsu, vol. I, Plates 1-110, Scenes of King Herihor in the Court, Chicago, Illinois, The Oriental Institute of the University of Chicago, pls. 31: 1-2, 102: 2; Kitchen, K. A., (1980). Ramesside inscriptions: Historical and Biographical, vol. III, Blackwell, Oxford, p. 576: 11; Nyslon, H. H. and Murnane, W., J. eds., (1981), pl. 2; Kitchen, K. A., (1983). Ramesside inscriptions: Historical and Biographical, vol. VI, Blackwell, Oxford, pp. 71: 3, 549: 3; El-Sayed, R., (1999). 'À la Recherche des Statues Inédites de la Cachette de ... Inédites de la Cachette de Karnak au Musée du Caire (I)', Annales du Service des antiquités de l'Égypte 74, Le Caire, p. 144; Leitz, Ch., (2002). Lexikon der Ägyptischen Götter und Götterbezeichnungen, Band VII, šPeeters en Department Oosterse Studies, Leuven; Paris, p. 259.

(127) Rossi, F., Pleyte, W., (1869). Papyrus de Turin, E. J. Brill, Leide, pl. CXXV; The Epigraphic Survey, (1940), pl. 201: The Epigraphic Survey, (1957). Medinet Habu, vol. V, The Temple Proper, Part I, The Portico, the Treasury, and Chapels Adjoining the First Hypostyle Hall with Marginal Material from the Forecourts, The University of Chicago press, Chicago, Illinois, pl. 261 ((B) Middle); Grumach, I. Sh., (1972). Untersuchungen zur Lebenslehre des Amenope, Deutscher Kunstverlag, München, Berlin, p. 21; Goyon, J.-C., (1972). Confirmation du pouvoir royal au Nouvel An: [Brooklyn Museum papyrus 47.218.50], Institut Français d'Archéologie Orientale, Le Caire, p. 66; Kitchen, K. A., (1975). Ramesside inscriptions: Historical and Biographical, vol. I, Blackwell, Oxford, p. 2: 6; The Epigraphic Survey, (1979), pls.102: 2; Nyslon, H. H. and Murnane, W., J. eds., (1981), pl. 223: 6; Kitchen, K. A., (1982). Ramesside inscriptions: Historical and Biographical, vol. IV, Blackwell, Oxford, p. 199: 2; Kitchen, K. A., (1983), vol. VI, p. 15: 16; 452:4-5; 1; Ritner, R. K., (1994). Denderite Temple Hierarchy and the Family of Theban High Priest Nebwenenef: Block Statue OIM 10729, In: D. P. Silverman, ed., For His Ka: Essays Offered in Memory of Klaus Baer, Oriental Institute of the University of Chicago, Chicago, p. 210.

(128) Moens, M.-F., (1985). The Procession of the God Min to the htjw-Garden, Studien zur Altägyptischen Kultur 12, Hambourg, p. 70.

(129) Erman, A., (1927). The Literature of the ancient Egyptians : Poems, Narratives, and Manuals of Instruction, from the Third and Second Millenia B.C., Translated by Aylward Manley Blackman, Methuen \& Co., London, pp. 137-138; Frankfort, H., (1948). Kingship and the Gods: A Study of Ancient Near Eastern Religion as the Integration of Society and Nature, The University of Chicago Press, Chicago, pp. 188-189; Kees, H., (1956), pp. 152, 200-201, 350; Goyon, J.-C., (1972), p. 66.

(130) Otto, E., (1966). Osiris und Amun: Kult und Heilige Stätten, Hirmer Verlag München, München, p. 123.

(131) Christophe, L.-A., (1955), pp. 70, 114; Nyslon, H. H. and Murnane, W., J. ed., (1981), pls. 135: 1, 252: 1 (right); Cornelius, I., (1994). The Iconography of the Canaanite Gods Reshef and Ba'al: Late Bronze and Iron Age Periods (c 1500 - 1000 BCE), University Press, Fribourg, pl. 21; Leitz, Ch., (2002). Lexikon der Ägyptischen Götter und Götterbezeichnungen, Band III, p-nbw, Dudley, MA: Uitgeverij Peeters en Department Oosterse Studies, Leuven, Paris, p. 291. (132) Davies, N. De G., (1953). The Temple of Hibis in El Khargeh Oasis, part III, The Decoration, the Metropolitan Museum of Art, New York, pl. 10: 1 (left); Tosi, M. and Roccati, A., (1972). Stele e Altre Epigrafi di Deir el Medina n. 50001 - n. 50262, Edizioni d'Arte Fratelli Pozzo, Torino, p. 103; Kitchen, K. A., (1980), p. 621, 6; Nyslon, H. H. and Murnane, W., J. eds., (1981), pl. 195: 2; Leitz, Ch., (2002), Band VII, p. 259.

(133) Kitchen, K. A., (1980), p. 576: 11; Christophe, L.-A., (1955), p. 54 (271-274), 83 (271274); Kuentz, Ch., (1971). La Face sud du Massif est du Pylône de Ramses II à Louxor, Centre de Documentation et d'Études sur l'Ancienne Égypte, Le Caire, pl. XVII; Tosi, M., Roccati, A., (1972), pp. 128, 303; Kitchen, K. A., (1979). Ramesside inscriptions: Historical and Biographical, vol. II, Blackwell, Oxford, p. 757: 16, 761: 2; Leitz, Ch., (2002), Band VII, p. 259. 
(134) Wilkinson, J. G., (1878), p. 24 (no. 504).

(135) Sethe, K., (1929). Amun und die Acht Urgötter von Hermopolis: Eine Untersuchung über Ursprung und Wesen des Aegyptischen Götterkönigs, Verlag der Akademie der Wissenschaften, Berlin, p. 20; Gauthier, H., (1931), pp. 137.

(136) Najovits, S., (2003). Egypt, Trunk of the Tree, vol. II, A Modern Survey of and Ancient Land, Algora publishing, New York, p. 85.

(137) Gauthier, H., (1931), pp. 135-137; Leitz, Ch., (2002), Band VII, pp. 258-260.

(138) Leitz, Ch., (2002), Band VII, p. 259.

(139) Brunner-Traut, E., (1982), p. 142.

(140) Jacobsohn, H., (1939), p. 35.

(141) Lurson, B., (2005), p. 118.

(142) Gauthier, H., (1931), p. 228; Brunner-Traut, E., (1982), p. 143.

(143) Jacobsohn, H., (1939), p. 35; Brunner-Traut, E., (1982), p. 143; Moens, M.-F., (1985), p. 63.

(144) Gauthier, H., (1931), p. 225.

(145) Brunner-Traut, E., (1982), p. 143.

(146) Schott, S., (1956). 'Totenbuchspruch 175 in einem Ritual zur Vernichtung von Feinden', Mitteilungen des Deutschen Archäologischen Instituts, Abteilung Kairo 14, Wiesbaden, pp. 184-185; Caminos, R. A., (1958). The Chronicle of Prince Osorkon, Analecta Orientalia, Rome 37, pp. 48-51; Zandee, J., (1977). Death as an Enemy: According to Ancient Egyptian Conception, Arno press, a New York company, New York, p. 155; Fischer, H. G., (1978). 'Five Inscriptions of the Old Kingdom', Zeitschrift für Äyptische Sprache und Altertumskunde, Leipzig, Berlin 105, p. 56; Graves-Brown, C. A., (2010). The Ideological Significance of Flint in Dynastic Egypt, vol. 1, unpublished PhD Thesis, Institute of Archaeology, College University, p. 178.

(147) Needler, W., (1956). 'A Flint Knife of King Djer', The Journal of Egyptian Archaeology 42, Londres, p. 43, pl. 3; Wilkinson, T., (1999). Early Dynastic Egypt, Routledge, London, New York, pp. 266-267; Wartin, L., (2004). 'Les Sacrifices Humains à Abydos lors des Funérailles des Rois de la Iére Dynastie: Un Mirage Thinite', Groupe de Recherche Européen pour l'Archéologie au Levant 2, Paris, pp. 6-17.

(148) Edwards, E. S., Gadd, C. J. and Hammond, N. G. L. eds., (1971). Early History of the Middle East, The University Press, Cambridge, p. 508; Posener, G., (1975). 'Ächtungstexte', Lexikon der Ägyptologie I, Harrassowitz Verlag, Wiesbaden, pp. 67-69; Osing, J., (1977). 'Ächtungstexte aus dem Alten Reich (II)', Mitteilungen des Deutschen Archäologischen Instituts, Abteilung Kairo 32, Wiesbaden, pp. 133-185, pls. 40-51; Koenig, Y., (1990). 'Les Textes d'Envoûtement de Mirgissa', Revue d'Égyptologie, la Société Française d'Égyptologie 41, Paris, pp. 101-125; Ritner, R. K., (1993). The Mechanics of Ancient Egyptian Magical Practice, The Oriental Institute of the University of Chicago, Chicago, pp. 136-142; Pinch, G., (1994). Magic in ancient Egypt, British Museum Press, London, pp. 92-93; Seidlmayer, S. J., (2001). 'Execration Texts', In: D. B. Redford, ed., The Oxford Encyclopedia of Ancient Egypt, vol. I, Oxford, pp. 487-498; Pinch, G., (2014). Magie und Raum. Der Magische Schutz Ausgewählter Räume im Alten Ägypten nebst einem Vergleich zu Angrenzenden Kulturbereichen, Mohr Siebeck, Tübingen, pp. 65-87.

(149) Derchain, Ph., (1971). Elkab. I. Les Monuments Religieux à l'entrée de l'ouady Hellal, Fondation Egyptologique Reine Elisabeth, Bruxelles, pp. 61-62 (no. 58).

(150) For further informaion about the harvesting of the emmer in ancient Egypt, see: Murray, M. A., (2000), pp. 520-524.

(151) Wainwright, G. A., (1935). 'Some Celestial Associations of Min', The Journal of Egyptian Archaeology 21, Londres, pp.152, 170; Kees, H., (1956), p. 200; Junker, J., (1961). Die Geisteshaltung der Ägypter in der Frühzeit, H. Böhlaus : Komissionsverlag der Österreichischen Akademie der Wissenschaften, Graz, Wien, Köln, pp. 132-133. 
(152) Daressy, G., (1897), p. 125; Gauthier, H., (1931), p. 231.

(153) Bleeker, C. J., (1956), p. 84.

(154) Bleeker, C. J., (1956), p. 83.

(155) Lurson, B., (2005), p. 117.

(156) De Rochemonteix, M., Chassinat, E., (1984), p. 394:12.

(157) Gauthier, H., (1931), p. 53.

(158) Bleeker, C. J., (1956), p. 83.

(159) Fischer, H. G., (1972). 'Offerings for an Old Kingdom Granary Official', Bulletin of the Detroit Institute of Arts 51, The University of Chicago Press, Chicago, p. 73.

(160) Piankoff, A., (1954). The Tomb of Ramesses VI, Pantheon Books, New York, fig. 48; Hornung, E., (1998). Die Nachtfahrt der Sonne: Eine Altägyptische Beschreibung des Jenseits, Artemis \& Winkler, Düsseldorf, Zürich, p. 128.

(161) Hornung, E., (1979). Das Buch von den Pforten des Jenseits nach den Versionen des Neuen Reiches, vol. I, Éditions de Belles-Lettres, Genève, pp. 264-268; Hornung, E., (1998), pp. 131-132; Wiebach-Koepke, S., (2003). Phänomenologie der BewegungsabLexikon der Ägyptologieufe im Jenseitskonzept der Unterweltbücher Amduat und Pfortenbuch und der liturgischen «Sonnenlitanei», vol. 2, Annotierte Transkription und Übersetzung Schautafeln, Harrassowitz, Wiesbaden, pp. 290-295; Hornung, E., (2014). The Egyptian Book of Gates, Living Human Heritage Publications, Zürich, pp. 256-261.

(162) Hornung, E., (1979), pp. 260-261; Hornung, E., (1998), pp. 128-129; Wiebach-Koepke, S., Wiebach-Koepke, S., (2003), pp. 290-291; Hornung, E., (2014), p. 250.

(163) Gauthier, H., (1931), p. 225.

(164) Fairman, H. W., (1954 ). 'Worship and Festivals in an Egyptian Temple', Bulletin of the John Rylands Library Manchester 37, Manchester, p. 199.

(165) De Rochemonteix, M. and Chassinat, E., (1984), p. 280 (Tableau I'e. 2 g. VIII).

(166) Leibovitch, J., (1953). 'Gods of Agriculture and Welfare in Ancient Egypt', Journal of Near Eastern Studies 12, pp. 78 (5), 105.

(167) De Rochemonteix, M. and Chassinat, E., (1984), p. 384:2 (Tableau Nn. 3g.); Chassinat, É., (1929), pl. XXXI (a).

(168) Wilson, P., (1991), pp. 42, 222.

(169) Bleeker, C. J., (1956), p. 83.

(170) Bleeker, C. J., (1956), p. 83.

(171) Lepsius, K. R., (1972), pls. 163-164 (a)

(172) The Epigraphic Survey, (1940), pl. 205 (b).

(173) Bleeker, C. J., (1956), p. 82 (no. 18).

(174) See for example the tombs of Amenemopet (TT 215) and Sennedjem (TT 1) at Deir el Medineh that date back to the earlier reign of Ramesses II and his co-regency with Sety I. Toda, E., (1887), pl. opposite p. 45; Campbell, C., (1912), pp. 159-167, pl. on p. 160; Wreszinski, W., (1923), pls. 14, 19 (a); Weigall, A. E. P., (1924). Ancient Egyptian Works of Art, T. Fischer Unwin Ltd, London, p. 258; Capart, J. and Werbrouk, M., (1925). Thèbes: La Gloire d' un Grand Passé, chez Vromant \& Cie, coll, Bruxelles, p. 339, fig. 250; Jourdain, G., (1939), p. 31, pls. XIX, XXI; Bruyère, B., (1959), pp. 36-37, pl. XXVII; Hodel-Hoenes, S., (2000), pp. 253255, figs. 181-183.

(175) Brand, P. J., (2007). Veils, Votives, and Marginalia: The Use of Sacred Space at Karnak and Luxor, In: P. F. Dorman and B. M. Bryan, eds., Sacred Space and Sacred Function in Ancient Thebes: Occasional Proceedings of the Theban Workshop, The Oriental Institute of the University of Chicago, Chicago, Illinois, p. 57.

(176) Hölscher, U., (1941), p. 8. For the connection between the pylon and the sun, see: Wilkinson, R. H., (2000), p. 60.

(177) Hölscher, U., (1941), p. 16.

(178) Gardiner, A. H., (1931), p. 40, pl. XIXA (5-6); Kitchen, K. A., (1983), vol. VI, p. 227: 8. 
(179) Bleeker, C. J., (1956), p. 47.

(180) Sethe, K., (1930). Urgeschichte und älteste Religion der Ägypter, Deutsche Morgenländische Gesellschaft, Leipzig, p. 166.

(181) Kees, H., (1956), p. 44.

(182) Gardiner, A. H., (1931). The Library of A. Chester Beatty: Description of a Hieratic Papyrus with a Mythological Story, Love-Songs, and Other Miscellaneous Texts, The Oxford University press : Emery Walker Limited, London, p. 23, no. 1; Griffiths, J. G., (1960), p. 46; Pinch, G., (2002). Egyptian Mythology: A Guide to the Gods, Goddesses, and Traditions of Ancient Egypt, Oxford University Press, Oxford, p. 165.

(183) Ogdon, J., (1985-1986). 'Some Notes on the Iconography of God Min', Bulletin of the Egyptological Seminar 7, Egyptological Seminar of New York, New York, pp. 29-36.

(184) Badawy, A., (1959). 'Min, the Cosmic Fertility God of Egypt', Mitteilungen des Instituts für Orientforschung 7 (2), Berlin, p. 168.

(185) De Buck, A., (1951), p. 204 (d)-205 (c); Faulkner, R. O., (1973), p. 263.

(186) Bleeker, C. J., (1956), p. 81.

(187) Wainwright, G. A., (1934). 'Some Aspects of Amun', The Journal of Egyptian Archaeology 20, Londres, pp. 140, 146; Bleeker, C. J., (1956), p. 49; Wilkinson, R. H., (2003), p. 115.

(188) Kees viewed this object as a fan or a protective shade that played a protective role to defend god Min against the heat of the sun when he left during his ritual processions. Kees, H., (1912). Der Opfertanz des Ägyptischen Königs, J. C. Hinrichs'sche Buchhandlung, Leipzig, p. 128.

(189) Gauthier, H., (1931), p. 151.

(190) Keimer, L., (1924). 'Die Pflanze des Gottes Min', Zeitschrift für Äyptische Sprache und Altertumskunde, Leipzig, Berlin 59, p. 143; Keimer, L., (1924). Die Gartenpflanzen im Alten Ägypten: Ägyptologische Studien, Band I, Hoffmann und Campe Verlag, Hamburg, Berlin, p. 6; Gardiner, A. H., (1931), p. 22, no. 1; Gauthier, H., (1931), p. 166; Kees, H., (1956), p. 91; Griffiths, J. G., (1960), p. 46; Germer, R., (1980). 'Die Bedeutung des Lattichs als Pflanze des Min', Studien zur Altägyptischen Kultur 8, Hambourg, p. 87; Germer, R., (1980). 'Lattich', Lexikon der Ägyptologie III, Harrassowitz Verlag, Wiesbaden, p. 939.

(191) Griffiths, J. G., (1960), p. 42.

(192) Keimer, L., (1924), Band I, pp. 2-3.

(193) Frazer, J. G., (1922). The Golden Bough: A Study in Magic and Religion, Abridged Edition, London, pp. 404a-406a.

(194) Gauthier, H., (1931), p. 226; Bleeker, C. J., (1956), p. 87.

(195) Leitz, Ch., (2002). Lexikon der ägyptischen Götter und Götterbezeichnungen, Band V, hh, MA : Uitgeverij Peeters en Department Oosterse Studies, Leuven, Paris, Dudley, p. 44; Hart, G., (1986), p. 75.

(196) Gesellensetter, J. S., (1997). Das Sechet-Iaru: Untersuchungen zur Vignette des Kapitels 110 im Ägyptischen Totenbuch, Unpublished PhD Thesis, Philosophical Faculty I of the Julius Maximilians University of Würzburg, Würzburg, pp. 56, 204.

(197) Sabbahy, L. K. ed., (2019). All Things Ancient Egypt: An Encyclopedia of the Ancient Egyptian World, vol. I, Greenwood, Santa Barbara, California, p. 13.

(198) Sethe, K., (1930), p. 166.

(199) Helck, W., (1987). Untersuchungen zur Thinitenzeit, Harrassowitz, Wiesbaden, p. 45.

(200) Hart, G., (1986), pp. 75-76.

(201) Hart, G., (1986), p. 76; Roth, A. M., (2000). Father Earth, Mother Sky: Ancient Egyptian

Beliefs about Conception and Fertility, In: A. E. Rautman, ed., Reading the Body: 
Representations and Remains in the Archaeological Record, University of Pennsylvania Press, Philadelphia, p. 191.

(202) Naville, E., Lewis, T. H., Tylor, J. J. and Griffith, F. Ll., (1894). The Tomb of Paheri at el Kab, The Egypt Exploration Fund, London, pl. III; Duell, P., (1938). The Mastaba of Mereruka, Part II, Chambers A 11-13, Doorjambs and Inscriptions of Chambers A 1-21, Tomb Chamber, Exterior, Plates 104-219, The University of Chicago Press, Chicago, Illinois, pl. 169; Murray, M. A., (2000), p. 522.

(203) Vandier, J., (1978), Paris, p. 88.

(204) Schäfer, H., (1974). Principles of Egyptian Art, Clarendon Press, Oxford, p. 295.

(205) Davies, W. V., (1982). 'The Origin of the Blue Crown', The Journal of Egyptian Archaeology 68, Londres, pp. 69-70; Johnson, S. B., (1990). The Cobra Goddess of Ancient Egypt: Predynastic, Early Dynastic, and Old Kingdom Periods, Kegan Paul international, London, New York, pp. 5-6; Hardwick, T., (2003). 'The Iconography of the Blue Crown in the New Kingdom', The Journal of Egyptian Archaeology 89, Londres, p. 118.

(206) See for example: Gardiner, A., (1953) 'The Coronation of King Haremhab', The Journal of Egyptian Archaeology 39, Londres, pp. 27-28.

(207) Davies, W. V., (1982), pp. 75-76.

(208) Wilkinson, R. H., (1994), p. 107.

(209) Ritner, R. K., (1993), p. 87; Hardwick, T., (2003), p. 120.

(210) Wilkinson, T. A.H., (1999). Early Dynastic Egypt, Routledge, London, New York, pp. 161-162.

(211) Gesellensetter, J. S., (1997), p. 12.

(212) Vandier, J., (1978), p. 81.

(213) Gauthier, H., (1931), pp. 227-228.

(214) Lucas, A., (1962). Ancient Egyptian Materials and Industries, Fourth Edition, Edward Arnold \& Co., London, pp. 228-229.

(215) Erman, A. and Grapow, H., (1971). Wörterbuch der Ägyptischen Sprache, Band V, Akademie Verlag, Berlin, p. 124:10-12.

(216) Brunner-Traut, E., (1977). 'Fabre', Lexikon der Ägyptologie II, Harrassowitz Verlag, Wiesbaden, pp. 118-119; DuQuesne, T., (1996). Black and Gold God: Colour Symbolism of the God Anubis with Observations on the Phenomenology of Colour in Egyptian and Comparative Religion, Da'th Scholarly Services: Darengo Publications, London, p. 18.

(217) Erman, A. and Grapow, H., (1971), Band V, p. 123: 11.

(218) Petrie, W. M. F., (1896). Koptos, Bernard Quaritch, London, p. 11.

(219) Kees, H., (1943). Farbensymbolik in Ägyptischen Religiösen Texten, Vandenhoeck \& Ruprecht, Göttingen, p. 416; Bleeker, C. J., (1956), pp. 49; Munro, I., (1983). Das ZeltHeiligtum des Min, Deutscher Kunstverlag, München, Berlin, pp. 1-2.

(220) Lucas, A., (1962), p. 248.

(221) Faulkner, R. O., (1962), p. 86; Erman, A. and Grapow, H., (1971), Band I, pp. 486: 14487:7; Helck, W., (1977), pp. 587; Hannig, L., (2003), pp. 428-429.

(222) Erman, A. and Grapow, H., (1971). Wörterbuch der Ägyptischen Sprache, Band II, Akademie Verlag, Berlin pp. 237: 6-239:13.

(223) DuQuesne, T., (1996), p. 16.

(224) Erman, A. and Grapow, H., (1971), Band II, p. 240: 7-9.

(225) Bleeker, C. J., (1956), p. 83.

(226) The Epigraphic Survey, (1940), pl. 215 (c); Helck, W., (1968), p. 82; Brand, P. J., Feleg, R. E. and Murnane, W. J., (2018), vol. 1, Part 2, p. 69.

(227) Helck, W., (1968), p. 82. 
(228) Lepsius, K. R., (1972), pls. 163-164 (a).

(229) The Epigraphic Survey, (1940), pl. 205 (b).

(230) Bleeker, C. J., (1956), p. 82 (no. 18).

(231) Gauthier, H., (1931), pp. 61-63 (5); Daressy, G., (1897), p. 124; Jacobsohn, H., (1939), p.

34; Bleeker, C. J., (1956), p. 82 (no. 18); Lepsius, K. R., (1972), pls. 163-164 (a).

(232) Daressy, G., (1897), p. 124; Gauthier, H., (1931), pp. 61-63 (5); Jacobsohn, H., (1939), p.

34; Lepsius, K. R., (1972), pls. 163-164 (a).

(233) Gauthier, H., (1931), p. 229; Additionally, she is the only female represented in the festival of god Min. Jacobsohn, H., (1939), p. 34 (no. 9).

(234) Hart, G., (1986), pp. 15-16.

(235) Jacobsohn, H., (1939), p. 34.

(236) Gauthier, H., (1931), p. 228; The Epigraphic Survey, (1940), pl. 205 (b); Bleeker, C. J., (1956), p. 82 (no. 18); Lepsius, K. R., (1972), pls. 163-164 (a).

(237) Gauthier, H., (1931), p. 228.

(238) Naydler, J., (1996). Temple of the Cosmos: The Ancient Egyptian Experience of the Sacred, Inner Traditions, Rochester, Vermont, p. 89.

(239) Wilkinson, R. H., (2003), p. 115.

(240) Wilkinson, R. H., (1994). Symbol \& Magic in Egyptian Art, Thames and Hudson, London, pp. 136, 146 (no. 100).

(241) Wilkinson, R. H., (1994), pp. 136, 146 (no. 100).

(242) Wilkinson, R. H., (1994), pp. 135, 146 (no. 100).

(243) Piankoff, A., (1954), p. 279-282; Hornung, E., (1963). Das Amduat, Die Schrift des Verborgenen Raumes, Herausgegeben nach Texten aus den Gräbern des Neuen Reiches, Harrassowitz, Wiesbaden, p. 125, 127-134; Assman, J., (1969). Liturgische Lieder an den Sonnengott: Untersuchungen zur altägyptischen Hymnik. I, Bruno Hessling, Berlin, p. 89, no. 13; Hornung, E., (1991). The Tomb of Pharaoh Seti I = Das Grab Sethos'I, Zürich, Artemis Verlag, Zürich, München, pl. 180-182; Hornung, E., (1992). Texte zum Amduat, Teil. II, Editions de Belles Lettres, Genève, pp. 523-530,533-540, 542, 544-546, 548-560; Darnell, J., (1995). The Enigmatic Netherworld Books of the Solar-Osirian Unity: Cryptographic Compositions in the Tombs of Tutankhamun, Ramesses VI, and Ramesses IX, A published PhD Thesis, The Faculty of the Division of the Humanities, University of Chicago, p. 453, no. 137; Hornung, E., (1998), p. 117; Wiebach-Koepke, S., (2003), pp. 108-119; Hornung, E., (2005). Immortal Pharaoh: The Tomb of Thutmose III: An Exhibition of Ancient Egyptian Objects from Antikenmuseum Basel und Sammlung Ludwig and the Kestner-Museum Hannover with the Facsimile of the Tomb of Thutmose III, Factum Arte, Madrid, p. 29.

(244) Ritner, R. K., (1993), p. 161.

(245) Chassinat, É., (1894). 'Le Livre de Protéger la Barque Divine', Recueil de Travaux Relatifs à la Philologie et l'archéologie Égyptienne et Assyriennes 16, Paris, pp. 106-108; Chassinat, É., (1928). Le Temple d'Edfou, Tome III, Institut Français d'Archéologie Orientale, Cairo, p. 315, pl. LXXX; Chassinat, É., (1929), pl. CCCXXII.

(246) Sauneron, S., (1962). Les fêtes Religieuses d'Esna aux Derniers Siècles du Paganisme, vol. 5, Institut Français d'Archéologie Orientale, Cairo, p. 269; Husson, C., (1977). L'Offrande du Miroir dans les Temples Égyptiens d'Époque Gréco-Romaine, Université de Lyon, Lyon, pp. 62-64.

(247) De Buck, A., (1954), p. 212 (a); Faulkner, R. O., (1977), p. 58.

(248) De Buck, A., (1954), pp. 211 (a), 227 (a); Faulkner, R. O., (1977), pp. 58, 60.

(249) The Epigraphic Survey, (1963), pl. 469. 


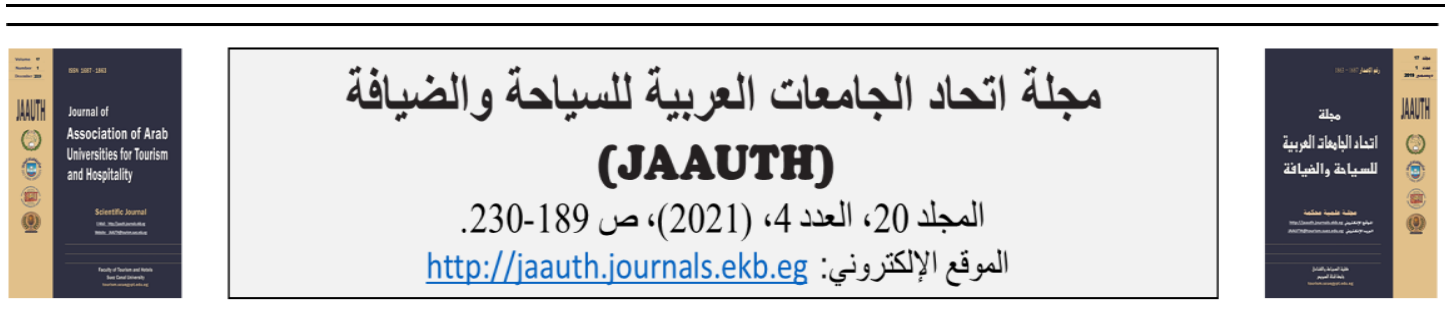

\section{طقس قطع الحبوب في معابد طيبة: نظرة عامة على مفهوم الخصوبة الإلهية والملكية يمنى عادل زكي نصر}

قسم الإرشاد السياحي، كلية السياحة والفنادق، جامعة الإسكندرية

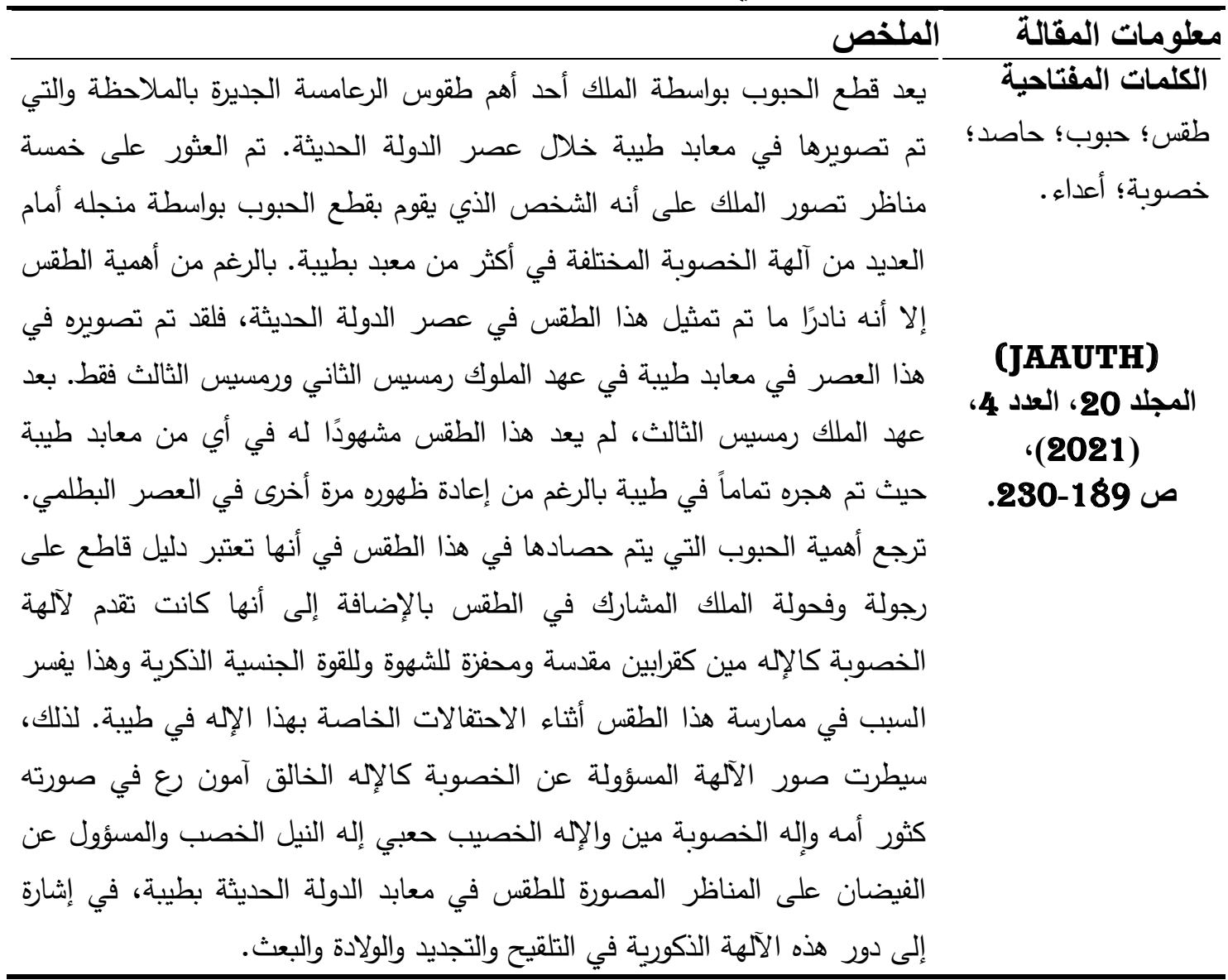

